Andrews University

Digital Commons @ Andrews University

Master's Theses

Graduate Research

1972

\title{
Development of an Instrument To Measure Student Attitudes Toward God Using Semantic Differential
}

Joyce A. Morse

Andrews University

Follow this and additional works at: https://digitalcommons.andrews.edu/theses

Part of the Educational Psychology Commons

\section{Recommended Citation}

Morse, Joyce A., "Development of an Instrument To Measure Student Attitudes Toward God Using Semantic Differential" (1972). Master's Theses. 149.

https://dx.doi.org/10.32597/theses/149

https://digitalcommons.andrews.edu/theses/149

This Thesis is brought to you for free and open access by the Graduate Research at Digital Commons @ Andrews University. It has been accepted for inclusion in Master's Theses by an authorized administrator of Digital Commons@ Andrews University. For more information, please contact repository@andrews.edu. 


\section{ABSTRACT OF GRADUATE STUDENT RESEARCH}

Thesis

Andrews University

Department of Education

Title: Development of an instrument to Measure student Attitudes

Toward 600 , Using Semartic Differential

Name of Researcher: Joyce A. Morse

Wane of Faculty Adviser(s): Dr. W. G. A. Futcher (chaimari),

Dr. Rith Murdoch, and Dr. Conrad Reichert

Date Completed: May 14, 1972

The study had two objectives; (1) to construct an instrunent which would nesure students' atitudes toward $6 \mathrm{~cd}$, end (2) to use the instrument in a sma11 pijot study to test its usefulness.

The instrument was patterned after the format of osgood's Semantic Differential and each subject was asked to make judgrents on five different concepts about God. Each concept was judged by pars of bipolar adjectives on a rating scale of one to five, with five being the nost positive. The thirteen bipolar adjective pains used tr the final instrument were used only after two item anajyses prowed then to be discriminatory in relation to the concepts. The same thirtest ocajes, ail evaliative in nature, vere used for each concept. 
A factor analysis, using a varinax rotation, yjelded two factors which accounted for an average of .75 of the total variance on each factor. Use of tucker's coefficient of congruence indicated a stability of factor patterns over different scales.

Two methods of determining reliability were used. The coefficient alpha reliability rose from a median of .7642 on Form I and .6627 on Form II on the initial administration to .9128 on the final adninistration. A test-retest reliability study was conducted using sixty-six students. The tests were administered approximately four weeks apart. The reliability of the test-retest study was .77 .

The instrument was submitted to a panel of six individuals, ald: educators and theologians, who vere asked to evaluate the instrument and judge whether or not it appeared to be a valid instrument for measuring attitudes toward God. All six experts judged the instrunenti to be valtd on the basis of face validity.

A smali pilot study was conducted to test the usefulness of the instrunert. Various statistical procedures vere used to analyze and compare the data obtained.

Three conciusions were reached: (1) an attitude scale for neesuring attituces toward cod can be developed; (2) the developnent cf nons are necessary for ease of jncepretation of the data; ard (3) whe pifot study demonstrated the usefulness of the instriment but give no clue to the sources of attitudes revealed. Trplications for further study were aiso included, along with scine precations. 
Andrews University

School of Graduate studies

DEVELOPMENT OF AN INSTRUNENT TO MEASURE STUDENT ATTITUDES

TOWARU GOD, USING SEMAITTIC DIFEFRENTIAL

\author{
A Thesis
}

\begin{abstract}
Presented in Partial Fulfillment
of the Requirements for the Degree

Master of Arts
\end{abstract}

by

Joyce Morse

May 1972

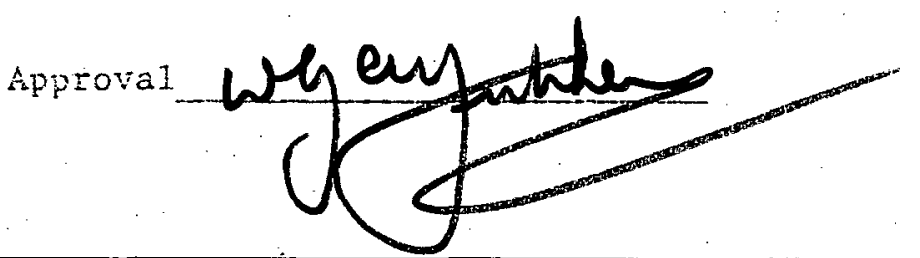


PREFACE

Seventh-day Adventist educators accept as one of their responsibilities the somewhat difficult'and nebulous task of helping to build within their students positive attitudes concerning God and His relationship to nen. There is no question about the diligence and effort of most teachers in trying to accomplish this goal. The problem is how to evaluate the progress being made in this area. Do students carry away from school with them attitudes which picture cod as someone who sincerely loves humanity, sinner as well as saint?

Do they experience joy jn communion with Him? Or do they, despite the best and most well-intentioned efforts, see God as a dictatorial. monarch waiting for man to sin so that punishment can be executed?

Until now, few instruments have been available which measire atcitudes toward God. There may be several reasons for this. Perhaps educators have assumed success in this area. Maybe the difficulty in constructing a suitable and accurate instrument was too great, or pexhaps educators and students aljke were reluctant to probe deeply into a matter as personal as an individual's attitude towart the Divine.

The purpose of this thesis, was to develop such an instrument-on instrument which would help teachers, supervisors, administrators, and stucars suduate how effective Seventh-day Adventist education has been in estabjishing positfve attitudes toward God in the hearts ard minds of the students. 
Grateful acknowledgment is made to the thesis committee:

Dr. W. G. A. Futcher; chatrman,

Dr. Ruth Murdoeh, and

Dr. Conrad Reichart

for their invaluable assistarce, to the Andrews University Computing Center for hours of rork, and espectally to the boys and girls in the Seventh-day Adventist elementary schools who are both the inspiration and the subject of this study. 
PREFACE . . . . . . . . . . . . . . . . . ii

IJIST OF TARLES . . . . . . . ........... . . vi

Chapter

I. THE PROBLEM . . . . . . . . . . . . . . I

Introduction ................... 1

Statement of the Problera ........... \&

Importance of the Study . . . .......... . . 4

Definition of Terms . . . . . . . . . . . . 5

Limitations . . . . . . . ....... . . . 6

Organization of paper............ . . 5

II. REVIEW OF LITERATUEE . . . . . . . . . . . . . . . 7

Introduction . . . . . . . . . . . . . . 7

Literature Review . . . . . . . . . . 7

III. SEMANTIC DIFEREENRIAI. . . . . . . . . . . . I4

Background and history . . . . . . . . . 14

Fornat . . . . . . . . . . . . . . . 17

Researching Using SD . . . . . . . . . . 19

Staats and Staats' Attitude Conditioning Study : 19

Scart-Measuring Attitudes Toward Mathenatics . . 20

Richmond and winte--Sociometric predictors

of Self Concept. . . . . . . . . . . 21.

IV. RESEARCH FROCEDURES . . . . . . . . ... . 23

Concepts . . . . . . . . . . . . . 23

scales ................. 27

Delinitation of scales . . . . . . . . 29

Fornat ................................. 37

Form of Concept siatement. . . . . . . . . 37

Number of Fossibie Responses . . . . . . . . . 37

Type of Test - Group or Indtuidual . . . . . . 38 
Chapter

Page

V. RELIABILITY AND VALIDITY ............. 40

Reliability. . . . . . . . . . . . 40

Factor Analystis of Concepts . . . . . . . . . 40

Coefficient Alpha and Test-Retest Reltability . . 44

Validity . . . . . . . . . . . . 4 45

VI. PILOT STUDY . . . . . . . . . . . . . . . 49

Comparison of Class Mean and Teacher Mezn . . . . 49

Construction and Comparison of D Matrices . . . . 51

Construction of Ij Matrices . . . . . . . 51

Comparison by observation . . . . . . . . 52

Comparison by Ramking. . . . . . . . . . 55

Comparison by Pearson Product Moment . . . . 55

VII. SUMPARY, CONCLUSIONS AND IMFLICATIONS . . . . . . 56

Summary ................... . . . . 56

Conclusions . . . . . . . . . . . . . 57

Irplications for Eurther Study . . . . . . . 58

BIBLIOGRAPHY . . . . . . . . . . . . . . 60

APPENDIX ............................... 63 
LIST OF TABLES

Table

Page

1. Point Multiserial Ratings on Each of Twenty

Ittems (Bipolar Adjective) for the Five

Concepts Attitude Scale - Forms I and II . . . . .

2. Mean Score, Standard Deviation, and

Reliability Coefficien Elpha for Five

Concepts - Attjtude Scale - Forms I

and II... . . . . . . . . . . . . . . . .

3. Point Multiserial Ratings of Each of

Thirteen Items on the Two Forms of the

Attitude Scale... . . . . . . . . . .

4. Staniard Deviation, Mean Score, and Reliability

Coefficient Alpha for Thirteen Bipolar

Adjective Pairs on Second Item Analysis . . . . . 36

5. Factor Analysis - Torm I.............. 4 I

6. Factor Analysis - Form II ............. 4 .

7. Coefficient of Congruence - Form I and Form II

First Factor Analysis . . . . . . . . . . . 42

8. Facror Analysis - Forn I - 7 Scales . . . . . . . 43

9. Factor Analysis - Forn II - 6 Scales . . . . . . 4 43

10. Coefficient of Congruence - Form I and Form II

Second Factor Ara1ysis... . . . . . . . . 44

11. Frequency of Adjective Selection by

Comittee of Experts. . . . . . . . . . . .

2. Jeacher and Ciass Mean for Each Concept

Teacher A . . . . . . . . . , . . . .

13. Teacher and Class Mean for Each Concept

Teacher B ............... . . 50

14. Scores for a Hypothetical Student

5 scailes and 2 Concepts . . . . . . . . . . 
IIST OF TABLES (CONTINUED)

Table

Page

15, D Matrix - Teacher B . . . . . . . . . . 53

16. D Matrix - Student 257 . . . . . . . . . 53 


\title{
CWERER
}

\author{
THE PROBLIM
}

\section{Intsoduction}

The Seventh-iay Adventist church at great expense and effort maintains a system of educition separate from that of the public schools. This system embraces all levels of education from preschool through the university.

One of the major purposes of Seventh-day Adventist elementary education is to assist the home in teaching boys and girls to love God and to help them be prepared to spend an eternity with him. How important it is then that students recognize God as a person not only worthy of their love, but as One who loves thein in return. A child who looks upon God as a God of love and justice learns to love Him in retum and covets an eternity in His presence. While the home is the primary source of children's attitudes, the teacher without a doubt, holds a place of major importance in the life of a child. The cinid sperds more waking hours with his teacher during the school year than with his parents. It would be logtcal to assume, therefore, that the teacher and his religious attitudes vould influence the religious attitudes of the students. This mey be accomplished consciously through studied effort on the 
part of the teacher as he plans the worship period, Bible class, and other activities throughout the school day. It may also be accomplished unconsciously through the teacher's casual talk witt the students, or by his own attitudes and actions.

The question which the school administrators must constantly face is, "How effective are the school and the teacher in their attempts to assist in the development of positive atritudes toward God?"

In an effort to evaluate the effectiveness of the church school system in this respect, each local conference in co-operation. with the union conference conducts periodic evaluations of the schools within its jurisdiction.

As the supervisor of elementary education in the centrai Union Conference of Seventh-day Adventists, the writer is frequentiy cailed upon to be a member of such a school evaluation committee. This compittee, conposed of local and union conference educational personnel, spends one day at the school to be evaluated and endeavors to deternine thether the self-evaluation which has previously been completed by the school board, parents, teachers, and church members is indeed a valid evaluation of the school and its program. The evaluative instrument contains several sections and it hes ustally been the duty of the writer to evaluate what has been wrtce: in the section entitled, "Basic Beliefs and Philosophy," which dejs specifically with beliefs concerning God, His relationship with men, and the school's responsibility in bringing man and God together. Iator, the lerge evaluation conmittee decides whether or 
not the school is meeting the objectives of the philosopity of education as outlined by the local comnittee studying that section.

In an effort to be as objective as possible, it was decided that interviews with a random sampling of students would give the evaluation committee rather good insights into the attitudes of the students concerning God and His relationship to man. This, then, was the evaluation plan followed.

Approximately one-half the students in each school being. evaiuated were interviewed. They were chosen by dropping a pencil on the student roster. Questions such as the following were asked:

1. Is your teacher a Christian?

2. What is the most important thing you've learned about cod?

3. Is your teacher anything like God? In what way?

4. If I asked your teacher what was his (her) most important. belief about God, what do you think he (she) would say?

5. What kind of a person is God? If the student began talking about His majesty, etc., he was directed to describe God as a PERSON.

Each student was interviewei individually and each response was jotted down for quict referral in making the final evaluation. As a result of these experiences the writer became most friterested in the attitudes students have developed concerning God and the neasurement of these attitudes. Several questions arose, nemely: 
1. Would rot a nore scientific, 3,e. reijable and valid, instrument designed specifically to measure students' attitudes toward God be helpful in general evaluations as well as in the more formal evaluations conducted by the union and conference educational leaders?

2. Was such an instrument available? Especially gas one available for use in Seventh-day Advertist schools?

\section{Statement of the Problem}

A careful search soon revealed that there was, indeed, a lack of an adequate instrument for measuring the student's attitude toward God.

The purpose of this study, then, was to develop an instrument Which covld be used to mescure the attitudes toward God held ty upper elementary. school students and to use the instrument in a pijot study to test its usefulness.

\section{Importance of the Study}

Since one of the primary purposes of Seventh-day Adventist education is to assist. the home in it's efforts to instill in boys and giris positive attitudes toward God, an effective instrunent wouid be of value to parents as they evaluate themselves and their family life sty]e. Teachers too could use the results as they plan ways in which they can provide more effective religious guidance to the students they tesch. Cortainly teachers would have cause for critical self-evaluation if, for exampie, most of their students ämcnstrated negative attitudes toward God. Providing for individual. 
reifgious differences would be made easier if teachers knew the atcitudes of their students.

Administrators and curriculum workers could be guided in their planning for new curriculum in religious education if they knew the attitudes students currently held toward God. In-service trainins for teachers would assume new meaning if they (teachers) could be show how important their cwn attitudes are in the transmission of positive attitudes. The use of such an instrument by evaluation committees as they attempt to deternine the effactiveress of a school in meeting its objectives, has aiready been noted.

\section{Definition ef Terms}

Certain terms as used in this study are briefly defined as E0.110ws:

Positive attitude toward God.--An attitude which enables tho indiridual to look upon God as someone to love, capable of loving in return. A God who is fair and understanding in His attitude toward humanity.

Negetive attitude toward God.--An attitude in which God is perceived as an suthoritarian dictator who uses every opportunity to judge and execute punishment on humanity.

Union conference.-- tn organizational subdivision of the Seventi-day Adventist church. It usualy embraces several states in temitory and acts in an advisory capacity to the state offices. Concept.- A division of Osgood's Semantic Differential which is the nain idea to be judged. 
Scales.--The bipolar adjective pairs which are used to judge the concept.

\section{Limitations}

This study was limited to upper elementary school students attending parochial schools. Wo attempt was made to cetermine reasons for the atitudes held. This could be a wortin-while subject for further research.

\section{Organization of Paper}

Chapter One of the paper deals with the problein, its beckground and importance. Chapter Two is a review of the literature which deals mainly with the teacher and his influence th the development of religious attitudes. Osgood's senantic differentiai, the research design, is the subject of Chapter Three. Included also in that chapter are reports of three research projects using semantic differential. The procedures used in the development of the instrument are explained in Chapter Four. Chapter Five is concerned with the reliability and validity of the instrument and chapter Six is a report on the small pilot study conducted. The last chapter, Chavter seven contains an evaluation of the work done and some Lifeas for further study. 
CLAETER JI

REVIEW OF LITERATURE

\section{Introduction}

To review literature based on research done in the area of measuring children's attitudes toward God, is almost impossible. A rather thorough search revealed little current iiterature concerned with children's attitudes toward God and the measurement of such attitudes.

Because the main concern of this study is the development of an effective instrument; and since it focuses primarily on the school. and teacher as they assist parents in their efforts to instill positive attituces toward God in the children, it seemed advisable to review literature that reflected the influence of the teacher on the values and attitudes of their students.

\section{Literature Review}

The concern over teaching moral and ethical values to children began as far back in history as ancient Greece and seemingly has continued to occupy the deepest thoughts of educators through the ages, Plato, in considering the moral problems of individual bebavior in relation to the social good, decided that a child should be tangint early in Iife how to discriminate between the good and harmifu. Aristotle saw the prime objective of education as being 
the development of an actively good person. John Dewey, who saw individual growth as the great purpose of education, established as the soie criterion for such growtits moral value (Michigan, 1968).

If the transmission of ethical and religious values was important in an ancient Greek and Athenian culture, its importance would be accentuated even more $i_{n}$ the age in which we now live--an age, for example, when the united States has hundreds of gallons of nerve gas so powerful that one gallon couid destroy eight billion people, more than twice the population of the entire world. At a time when the United States has fifty-three thousand atomic bombs stockpilee, each of which is hundreds of times more powerful than those used in World War II, it would seem that some type of ethical and religious training is imperative.

In recent years public systems of education attempted to provide curciculum naterials for high school and college teachers. to assist then in thejr efforts toward teaching values to their students. However, few curriculum guides for elementary teachers were located. This is, indeed, unfortunate for research in the area of growti and development has shown that elementary school students by their very nature fossess greater receptivity to the teaching of ethicaj and religious values.

Iiblett (1964, p. 101), in speaking of elementary students, states that young cilicen come to school as impressionable young personalities with certain possibilities and potentialities. They sncounter daky in the classroom and/or the play-ground, a vast number of nolding factors which tend to shape their characters--not 
the least of which is the beacher. Brown, in his book Not Minds Alone (1954, p. 3), continues with the idea that sone cf these molding factors are bound to be religious in nature; that ecucation camnot be complete without religion nor is religion complete without education. The elementary teacher must, therefore, become in the broadest sense not only a teacher of scholastic facts but an instructor in the religious factors which influence children.

Scientific studies have revealed two ways in which the teacher teaches ethical and religious values. The first, is through a systematic and structured teaching of values within various content areas such as religion, social studies, The second, is the unconscious influence of the teacher in the transmission of ethical and religious values. The latter method is, of course, more difficult to measure statistically, and deals more closely with the affective domain of the student. Dinkmeyer (1965) states that "the teachers behavior serves either to establish or change the child's concept of the world and people." According to Averit (1.931) each child is in essence saying to the teacher "How car I hear what you are sayjing when what you are comes thundering into my ear?"

Phenix (1966) in speaking of the potency or power of reijgious beachers states that they have great power, not because of what they teach verbally, but because of the actual fulfiliment of the teaching in the personal existence of the teacher. He, the teacher, says what he meane and means what he says, for the words that he speaks are symbols of what his life means. Brown $(1954 ;$ p. 87 ) has 
stated that the teacher, by example, should represent the kind of living that education at its best stands for. Niblett (1964, p. 28) stated that, if teachers are to be successful in teaching values, their own values must shine through their actions and the way they teach.

Niblett (1964, p.28) goes on to state that the teacher nost Iikely to be able to give moral education will be friendly, warm, and understanding. Being beaten over the head by a statement of decision the teacher beljeves to be correct, is rot going to do much for anyone's moral education. In speaking of understanding students LeFevre (1958, p. 15) says, "It is not only one of the keys to good teaching but it is also the key to communicating the Christian raith in action." Buber (LeFevre, 1958, p. 115j calls it a dialogue relationship between two persons in wilch there is a feeling of trust. When this is present the teaching learning process can become a process whereby the teacher exposes the student to the ethical and religious values he himself possesses. Harvey (1970) quoted Henry Adams as saying, "A teacher affects etermity! He can never teIl where his influence stops." In their study, Hartshorne and May (1928, p. 150) found that where the relationships between the teacher and student are characterized by an atmosphere cf good will, there was iess dereption on the part of the siudents.

$$
\text { In a recent survey in the state of Michigan (1968) five }
$$
hundred and fifty-two questionnaires were sent out asking if the educators felt teachirg ethical and religicus values was important 
to education today. Of the tro hundxed and sixty-nine questionnaires returned all felt it nuss be an intrinsic part of the total curriculun. An interesting sicelight was revealed however when the "free" statements written on the questionnaire by the educators were analyzed. Nearly all the respondents felt that if a student's ethical values are to be affected by public school education the teacher must set the example. Precepts will not do; teachers must demonstrate in their daily lives the standards of behavior expected from the youth.

$$
\text { An interesting study conducted by Victor H. Vroom (1959) }
$$

yielded severa]. significant insights into attitudes and their trans-mission. One of his findings is especially relevant to this paper, namely, that attitudes tend to be contagjous. Without conscious thought individuals tend to project their attitudes and to accept those of people they like.

According to Bermard (1965) the statement "as is the teacher, so is the school," is filled with meaning and truth. Without question a teacher shapes and molds the atmosphere of the classroom and directly affects the learning and atitude development of the students. The remarkable fact is that this influence begins almost imediately from the time the teacher begins working with a group of children. Boynton (1934) and his associates found, from a study of 70 teachers and over $1,000 \mathrm{fifth}$ and sixth graders, that the teacher's characteristics hegan to infivence the childxen in periods as short as two months.

Berrard (1965, p. 460) in speaking of the effect teachers have on the attitudes and behavior of students, states, "Numercus 
experimentai and cbservational studies confirm the fact that pupils Jearn what a teacher is as well as what he says. Pupiis absorb his attitudes, they reflect his mods, they share his convictions, they imitate his behavior, and they quote lis statements."

If educators in public school education recognize the tremendous inpact that teachers' lives have on the teaching of moral and ethical values, it would certajily seem that the educators in the Seventh-day Adventist system of schools should influence the values of their students to an even greater extent.

E1len G. White (1903, p. 280) states: "Chilaren axe quick to detect affectation or any other weaness or defect. The teacher can gain the respect of his pupils in no other way than by revealing in his own character the principles which he seeks to teach them. only as he does this in his daily association with them can he have a permanent influence over them for good."

In another article this same author (White, 1907) tell.s teachers that, when the love of Christ pervades their souls, they (teachers) will unconsciousiy teach it to others; by the same token criticism and evil thinking can be reproduced in the character of the children and youth (White, 2923, p. 269).

Philip Jackson (Frymeiter, 1969) has said that a teacher interacts with his class somewhere between six hundred and fifty to eleven hundred times a day and that each of these interactions in... fluences the values of a child. According to Frymeier (1969) research ir anthropclogy and social psychology makes one point very 
clear: children tend to beome the kinds of people their teachers are. 
CHAFTER III

SEMANTTC DIFPERENTIAL

Background and History

Semantic differential is not a test with a specific number of items and a final soore. It is rather a general way of getting at a certain type of information, i.e., a method of observing and measuring the psychological meanings of things, usually concepts. While it is true that meaning varịes from person to person, there is a central core or area of commonality in all meaning. For example; the word "church" may have different meanings for persons of the Roman Catholic arid the Jewish faiths. Each perceives "church" a: bit differently, indeed they may even use different names for the edicicos, but there is a commonality in the word church that has the same meaning for worshippers of all faiths.

Osgood and his associates invented the semantic differential, henceforth called SD, by postulating a semantic space, a region of some linkown dinensionality, wherein meaning lay. Using factor and thesaurus analysis, they developed sets of bipolar adjectives that would measure the meaning of various concepts or ideas as perceived by the person taking the test. Henceforth, the word "concept" as used in this paper refers to that part or division of Osgood's SD which will be judged by the "scales" or adjectives. 
Semantic space or "area of meaning," as envisioned and tested by Osgood has three dimensiors, evaluative, potency and activity. Kerlinger (1964, pp. 564-566) gives a fairly simple and understandable explanation of semantic space. He uses a room as a point of reference in his explanation. Imagine that three sticks could be ariven through the space in the room at right angles to each other, meeting in the center of the room and touching the walls, floor and ceiling, If the axes were labelled $x, y$ and $z$ and if meanjing lay in the space between the axes then any point in the space will have three mearings (the $x$ axis, the $y$ axis and the $z$ axis). For example one point may have three units on $x$, six units on $y_{s}$ and one unit on $z$.

Kerlinger then gives an example using a hypothetical two dimensional educational example. It is included here because of its clarity.

Suppose we have determined that there are two basic dimensions or factors of meaning. Our research has told us that most educational concepts, like SCHOOL, CURRICULUM, TEACHER, PRINCIPAL, and so on, can be related to two axes, $X$ and $Y$, which, for good reasons, we have named Evaluative and Potency. Now, if we have some way to measure things on $X$, Evaluative, and $Y$ Potency, then we can describe these things in the same manner as we did before. Suppose we measured certain concepts in a paricular school (by administering an appropriate instrument. to teachers, say). SCHOOL may turn out to be $(6,1), 6$ units on $x$ and 1 unit on $Y$, or, using seven-point scales, high on Evaluative and low on Potency. TEACHER nay turn out to be $(5,2)$, PUPiL $(5,-1)$, FARENT $(2,2)$, PRIFCIPA $(0,5)$, SUPERINTENDENT $(1,6)$, TEACHING $(6,2)$, STUDY $(5,1)$, LEARIING $(-2,3)$, and DISCIPLINE $(1,4)$.

From this information we are able to describe the perception of the school on the evaluative and potency dimensions. The values can then be plotted on a geometric axis figure similar to the one shown in igure $i$. 
FIGURE 1

VALUES OE CONCEPTS ON TWO AXES--X (EVALUATIVE)

AND $Y$ (POTENCY)

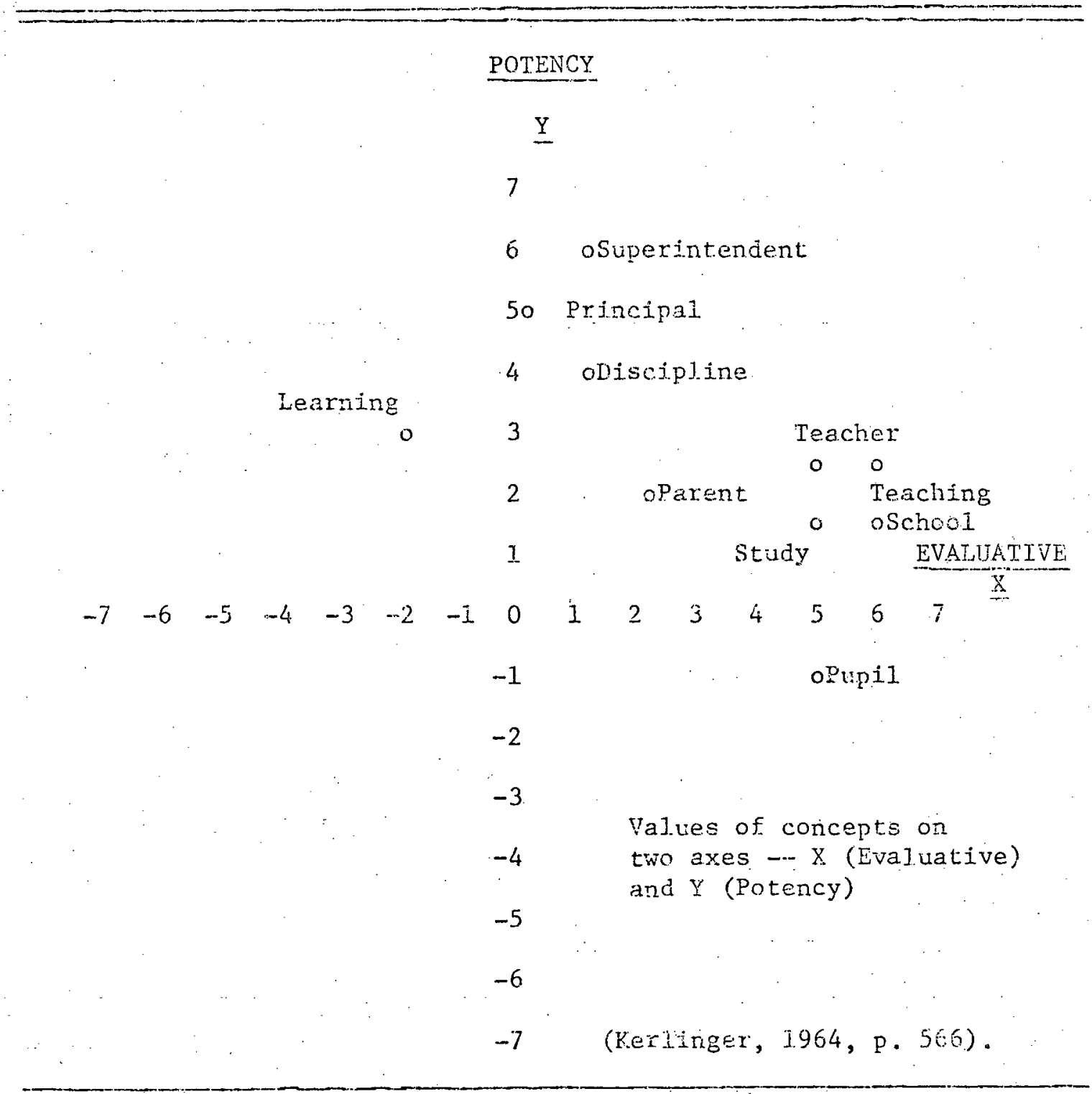

We now have a geometric, spatial, and quantitave description of the meaning of school on both the evaluative (goodness) and potency (strength) levels. 
From figure $I$ it can easily be seen that the principal is high on the potency scale but quite low on the evaluative scale. The parents rank about the same on both scales.

Thus we have a clear picture of what "school" means to this group of people. Quite possibly the meaning would vary from group to group and school to school.

The important things however, are that (1) the concepts concerning "school" have been defined by reference to two dimensions, and (2) the meaning of a concept comes not only from its relationship to the dimensions, potency and evaluative, but also from its relations to other concepts. In Figure 1, for example, "school" is closely related in meaning to "study," "teaching" and "teacher" but not related closely with superintendent.

\section{Format}

For actual use SD consists of two major components (I) a group of concepts which is to be judged and (2) a number of scales or pairs of bipolar adjectives chosen because of the specific purpose and objective of the research. These scales are usually seven point rating scales. Keriirger (1964, p. 571) states, however, that it is probably best to use a five point scale when dealing with children. As originally designed the adjective pairs vere to measure ali three dimensionalities of meaning. However when testing attitudes and values the "Evaluative" factor is usualiy the only one used (Kerlinger, 1964, p, 569). 
The actual format of SD is really riuite simple. The concegt to be judged is listed at top of the page and the adjective pairs directly follow. Sonetimes the adjectives are reversed. For example, instead of "beautiful---.gly," it might read "ugly-abeautiful." This is usually done at random and is used to counteract the tendency to mark the items without thinking about the meaning. In other words, the subject cannot go down the list and check all the scales at the same point. For example:

The School

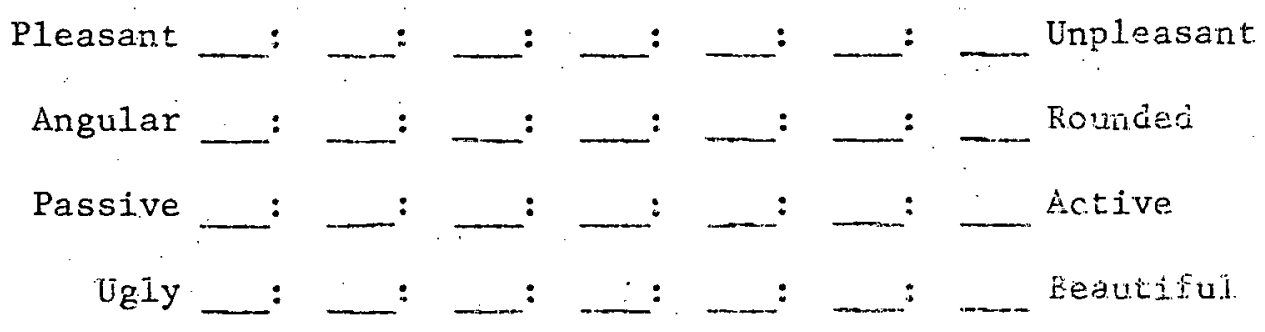

Each concept to be measured appears on a separate page in the test and the same bj.polar adjective pairs are used to judge each concept. Some researchers (Osgood, p. 81.) feel the results are improved when instead of having a concept at the top of the page, a sjgnificant word from the concept is placed by adjective pair No. I, another concept is judged by adjective pair 2; and siil another by adjective pair 3. Obviously then on the second page the concepts would be rotated so that each concept wouid be judged by each adjective pair. Thjs form would look ilke this:

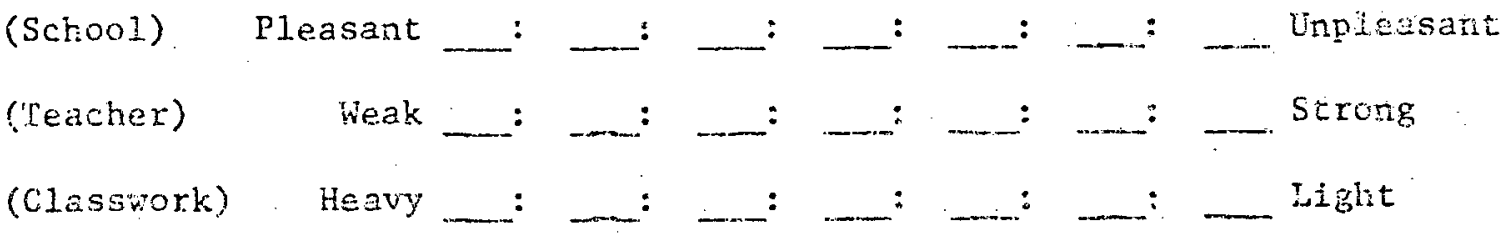


Still another researcher suggests that the students should be instructed to mark the first item on all pages first and then go back and mark the second item on all pages and ther mark item 3 , etc. (Osgood 1957, p. 81).

\section{Research Using SD}

The acceptance SD has received in psychological circles has been quite gratifying to Osgood and his associates. Educators have, however, been more reluctant to accept and use this form of measurement. Therefore any research included here is psychological by nature and is included because of its relevance to the writer's research.

Staats and Staats' Attitude Conditioning Study

This study is most interesting because in it, Staats attempted to ascertain if attitudes evoked by certain significant words could be changed by conditioning. Since attitudes are learned, reinforced and conveyed by words, could conditioning change them without the subject's being aivare of the change?

Two groups of subjects were used. In one part of the experiment both groups were presented six nationa1 names GERMAN, SWEDISH, ITALIAN, FRENCH, DUTCH, and GREEK. A word was said each time the nationality was projected onto the screen. SWEDISH and DUTCH were aiways evaluative words. For Group 1 DUTCH was paired with positive words, (happy, sacred) but SWEDISH was associated with negative words (ugly, bitter). The procedure was reversed for Group 2. After the conditioning an SI was given to the subjects. 
In the second experiment nale names were substituted for the names of nationalities. Using different subjects, the same conditioning was followed and again an SD was administered.

A $2 \times 2$ analysis of variance was used in analyzing the data. The dependent variables were the seven point S1) scores of the two conditioned words. Results showed that conditioning was affective in establishing a positive or negative "set" to the conditioned rords.

Scarf-Measuring Attitudes Torvard Mathematics

The investigator in this most interesing research had as her major objective, the measurement of the students' attitude toward mathenatics. She chose SD as her method of measurement because it possesses simpiicity of format, content and scoring.

As in inost attituinal scales using SD, the research was interested only in an evaluative expression of the student's attitude, therefore scales like Good: Bad, and Happy: Sad, were used.

The research was conducted on two groups of elementary schooi children. The first group had been exposed to an individualized approach, while the second had had only the conventional classroom situation.

The test was administered in 1969 to fourth, fifth and sixth grade students; 642 of the students had learned math by the IPI (Individualized Prescribed Instruction) method and 662 by the regular Ciassroom method.

In the statistical analysis of the data, the five point scale of SD was reduced to three by categorizing the responses into "Very 
Positive," "Positive," and "Not Positive" cells. Chi-square was the statistical technique chosen for the analysis.

The results of the research were quite interesting. For the concept "My Math Class is" which was evaluated in one instance by the scale Good:Bad, the students learning by the IfI method demonstrated a more positive attitude at the .01 level of significance. However, the results on the scale Happy: Sad, showed no significant difference. Two other concepts were used: "Doing Math Is" and "Taking a Math Test is." The results of the two scales, Good:Bad, and Happy:Sad, on these two concepts were like those for the first concept.

Results of the research seemed to indicate that IPI affects the attitudes of the students toward mathematics in a positive way.

Ricmond and White--Sociometric Fredictors of Sels concept

The purpose of this study was to isolate factors of selfesteem and of peer ratings and to determine significant relationships. between the derived factors.

Subjects were 204 eiementary pupils in grades five and six from two schools in two metropolitan areas of Georgi.a. Approximately half were black, disadvantaged pupils, and the rest were white with above average cultural advantages.

Two instruments were used. The Coppersmith SEI (Self-Esteem Inventory) was used to determine the student's atticude toward himself and twelve adjective pairs in the SD were used to rate several peer concepts in the classroom. A seven point scale was used for these adjective pairs. 
The students of cach class were divided into three subgroups. Each member of the subgroup was asked to do two things, (1) complete the SEI by checking the correct box to indicate whether or not the statement described "how he feels about himself" and (2) complete the SD for each member of his group. Thus each chjld would have about eight ratings by his peers.

The adjective pairs measured all three areas of semantic meaning, Evaluation, Foiency and Activity.

A factor anaiysis was conducted on the results of both tests and five factors emerged as being significant. (1) Lack of seif-. confidence (2) need for parental support (3) parental rejection (4) Iie scale (5) high ego-strength, characteristics of potential Leaders.

The conclusions of the researchers when they compared the correspondence between the factors of peer and seIf-concepts is that a child with high negative self-esteem is more apt to rate high on the Activity factors in the SD. This agrees with Coppersmith's thesis that the child with poise and seIf-assurance is more apt to be viewed favorably by his peers.

The studies which have been reviewed in this section were chosen from many read for two reasons. (1) They showed successfuI use of $\mathrm{SD}$ with middle to upper elementary students, and (2) they involved the measurement of attitudes toward something or someone. 
CHAPTER IV

RESEARCH PROCEDURES

\section{Concepts}

Osgood (1957, p. 77) states that the possible concepts which can be used in any one study using semartic differential are many and varied and that the type selected depends chiefly upon the interests of the investigator. Obviously time and effort would 1imit the coverage of all relevant corcepts, therefore it was arbitrarily decided that five concepts measuring different aspects of a child's attitude toward God would be acequate.

The dilemma which was faced at this point was, "which five of all the possible concepts concerning God should be used?" Osgood (1957, p. 79) feels that usually an investigator need use oniy what he calls "good judgment" with respect to his problem. He does give, however, three criteria which the investigator should recognize as he exercises his "good judgment." First, the investigator should try to select concepts for the meanings of which consideratle individual differences can ve expected. Secondly, the concepts should have a single unitary meaning for the individual and lastly, the concepts selected should be familiar to all subjects. Unfamiliar concepts will produce a "spurious" regression toward the middle of the scales for sone students. 
A search for appropriate concepts soon revealed that because of the wide selection avajable there would have to be sone additional criteria upon which to base consideration of suggested concepts. The criteria decided upon were: (1) the concept must be relevant to middle and upper grade students, (2) the concept must be within the understanding of the above mentioned age group and, (3) the corcept mist deal with the attributes of God as a person. Therefore, concepts of a deeply theological nature, concepts which were of more concern to adults than children and concepts which dealt with the magnitude and power of God were not consigered.

A list of seventeen concepts meeting these three criteria, as well as those suggested by Osgood, was finally cornpiled.

\section{POSSIBZE CONCEUTS}

1. God is

2. God's attitude toward men is

3. God's judgments are

4. God's demands on men are

5. God's attitudes toward sinners is

6. Jesus Christ is

7. The. writings of virs. E. G. White show a God who is

8. God's sabbath is

9. God's requirenents for Christians are

10. Christians are

11. Prayer is

12. God's requirenents for salvation are

13. God's punishment of the wicked is

14. God's vord, the Bible, is

15. God's commission to the worid is

16. God's attitude toward His people is

17. God's ten commandments are

This list was then given to a group of five Adventist educators and theologians al1 instructors at Andrews University. The writer met personaliy with each individual and asked hin to check the five 
concepts which in his opinion rould elicit responses concerning

God as a person.

The results of this selection were compiled simply by counting the number of votes each concept received and the final consideration was based on the following concepts:

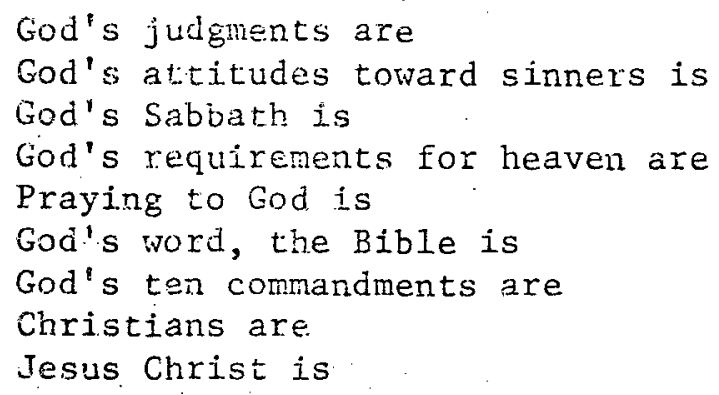

The five concepts which were finally selected vere chosen because they met two requirements, namely: (1) they had been chosen by at least three nembers of the committee and (2) they held special relevance for boys and girls. The five concepts choser are listed below:

\section{FINAL CONCEPTS}

God's atticude toward sinners is...

God's Sabbath is...

God's requirements for reaching heaven are... Fraying to God is... .

True Christians...

The concept "God's attitude toward sirners" was suggested by four of tive comittee members and was choser because every child has at some time been naughty and has had to be punished. The fear of confemation by God and eternal destruction at His hand can be very reai to children. How a child perceives God's atiftude toward him 
when he is naughty, and how he perceives God's feelings toward sinners will reflect his atutude toward God as a person.

"God's Sabbath" was chosen as a. final concept because it is the one commandment out of the ten which the children meet and deal with consistently and regularly. Seventh-day Adventists firmly believe that the Sabbath like the other ten conimands reveal to men the character of God. Proper observance of the seventh day Sabiath is important in Adventist homes and children in forming attitudes toward the Sabbath are forming attitudes about God and His character. This concept was chosen by all five individuals interviewed.

"Going to heaven" is of vital importance to Seventh-day Adventist children. Consequenty the requirements set down by God for reaching heaven become a major concern to them. Are God's requirements just or unjust; easy or hard; encouraging or discouraging? How children view God is reflected in their attitudes toward what He requires of them. The concept "God's requirements for reaching heaven," therefore seemed to be appropriate and relevant. It was chosen by three of the five persons who looked at the original seventeen concepts.

The major contact that children personaliy experience with God is through the avenue of prayer. This is especially true in seventhday Adventist circles where at a very early age children are taught to pray. These children are also taught that God hears and answers their prayers and enjoys baving them come to Hin with their petitions. Therefore because prayer is the one personal contact children have With God, it seems likely that their attitudes toward prayer would 
reflect a very personal inter-relationship and attitude toward the God to whom they pray. This concept, "Praying to God," was chosen by three of the five comittee members.

The last concept, "rrue Christians are.." was chosen by three of the comattee nembers and was selected primarily because (1) adults often stand in place of God to the children (2) children's attitudes toward God are often based upon their attitudes toward His professed followers.

\section{Scales}

The process of choosing scales is necessarily more structured than that for choosing concepts. The number of bi-polar adjective pairs which can be used is almost limitless.

It will be renembered from Chapter III chat originaily usgood designed semantic differential to measure three dimensionalities of semantic space; evaluative, strength or potency, and motion or activity. In the study of attitudes and values, however, the evaluative factor is used almost exclusively (Keriinger, 1964, p. 569).

Osgood gives two main criteria which determine the selection of the scales; (1) factor representativeness--in other words, are the adjectives evaiuative by rature; and, (2) relevance to the concepts usej.

The latter criterion, relevance, is much more difficult to satisfy than the former one. In some cases it is quite clear that the adjective pair is related to the concept. In others, however, reievance seens to be present, but is it really? The most obvious 
thing to do would be to we scales already included in Osgood"s list. However many of those adjectives are not particularly relevant to the concepts used in this study. For example, it is extremely doubtful that anyone would respond to God as being "bad" if the adjective pair "good-bad" were used.

A subtle point appears when speaking of the relevance of the scales to the concepts. It wilI be remembered from Chapter III that each concept uses the same set of scales. Some scales appear to have to relevance to some items. However, Osgood feels that since meanings are rich and complex, an apparently irrelevant adjective pair will probably turn out to have celevance in the mind of the subject (Kerlinger, p. 570).

A list of fifty adjective pairs was conpiled. Fach pair met the criteria listed above and was checked for readability by fiffit and sixth grade students using the Dale, Edgar and Chall readability scale. Obviously, a list of fifty bi-polar adjective pairs was too long. Wille Osgood's research proved that the slowest college student could make judgments at the rate of ten items (pairing particular concept with a particular scale) per minute or a cre hundred item test every fifteen minutes, it seened that with elementary students a smeller test vas most desirable. Therefore it was empirically decided that an instrument with ten scales for each of five concepts would be adequate.

The list of fifty adjective pairs were given to the same group of Adventist educators and theologians and they were asked to choose which adjoctive pairs seened to fit most closely with the concepts 
they had chosen. Reashis to their selection were also given and suggestions for additional adjective pairs were noted. As a result twenty adjective pairs were chosen for further consideration.

Delimitation of Scales

The twenty adjective pairs were divided into two groups of ten each. Each group was then placed with the five concepts and became form one and form two of the test. (See Appendix A and B).

The two forms were then administered to ninety-seven fifth and sixth grade students at the Laboratory School; Andrews University. Half. (48) of the students were administered form one and half (49) were administered form two.

An item analysis treating each concept as a separate test was then done. Tabje 1 shows which items had questionable or poor point multiserials based on the criteria that any point multiserial below thirty was questionable and any below twenty poor. (See Table 1). Table 2 shows the mean, standard deviation and reliability co-efficient alpha for each concept on the two forms.

As a result of the item analysis, the following bi-polar adjective pairs were deleted:

\section{Form I}

$\begin{array}{ll}\text { Watcinful } & \text { Unconcerned } \\ \text { Hot } & \text { Cold } \\ \text { Williag } & \text { Unwilling }\end{array}$

rorm II

Joyful Essential

Serious

Particular
Sed

Non-essential Bumorous

Liax 
TABIE 1

POTNT MULTTSERIAI RATINGS ON EACH OF TWENTY ITEMS

(BIPOLAR ADJECTIVE) FOR. THE FIVE CONCEPTS

ATTTTUDE SCALE =- FORMS I AND II

\begin{tabular}{|c|c|c|c|c|c|}
\hline Item & $\begin{array}{c}\text { Concept } 1 \\
\text { Attltude--Sinners }\end{array}$ & $\begin{array}{c}\text { Concept } 2 \\
\text { Sabbath }\end{array}$ & $\begin{array}{c}\text { Concept } 3 \\
\text { Reguirements-heaven }\end{array}$ & $\begin{array}{c}\text { Concept } 4 \\
\text { Praying to God }\end{array}$ & $\begin{array}{l}\text { Concept } 5 \\
\text { True Christ ans }\end{array}$ \\
\hline FORH I & $+\infty-2$ & & & & \\
\hline Exotting & & & & & \\
\hline 1. Buring & .63 & .64 & .54 & .61 & .65 \\
\hline Watchful & & & . & : & \\
\hline 2. Unconcerned & $.11 * * x$ & .36 & $.19 * *$ & .45 & $.28^{*}$ \\
\hline $\begin{array}{l}\text { Encouraging } \\
\text { 3. Discouraging }\end{array}$ & .74 & .63 & .51 & .38 & .33 \\
\hline $\begin{array}{l}\text { Lenient } \\
\text { 4. Strict }\end{array}$ & .42 & .44 & .48 & .42 & .64 \\
\hline $\begin{array}{r}\text { Pleasing } \\
\text { 5. Annoying }\end{array}$ & .70 & .76 & .47 & .58 & .66 \\
\hline $\begin{array}{l}\text { Approving } \\
\text { 6. Disapproving }\end{array}$ & .68 & .48 & $.23 \%$ & .60 & .56 \\
\hline 7. Hot & .64 & .69 & $.08 * *$ & .42 & $.24 *$ \\
\hline $\begin{array}{l}\text { Easy } \\
\text { 3. Hard }\end{array}$ & .50 & .51 & .48 & .46 & .59 \\
\hline $\begin{array}{l}\text { Willing } \\
\text { 9. Unwilling }\end{array}$ & .63 & .67 & .63 & .78 & $.17 * *$ \\
\hline $\begin{array}{l}\text { Understanding } \\
\text { 10. Indifferent }\end{array}$ & .41 & .65 & .43 & .73 & .54 \\
\hline
\end{tabular}




\section{TABLE 1 (CONTINUED)}

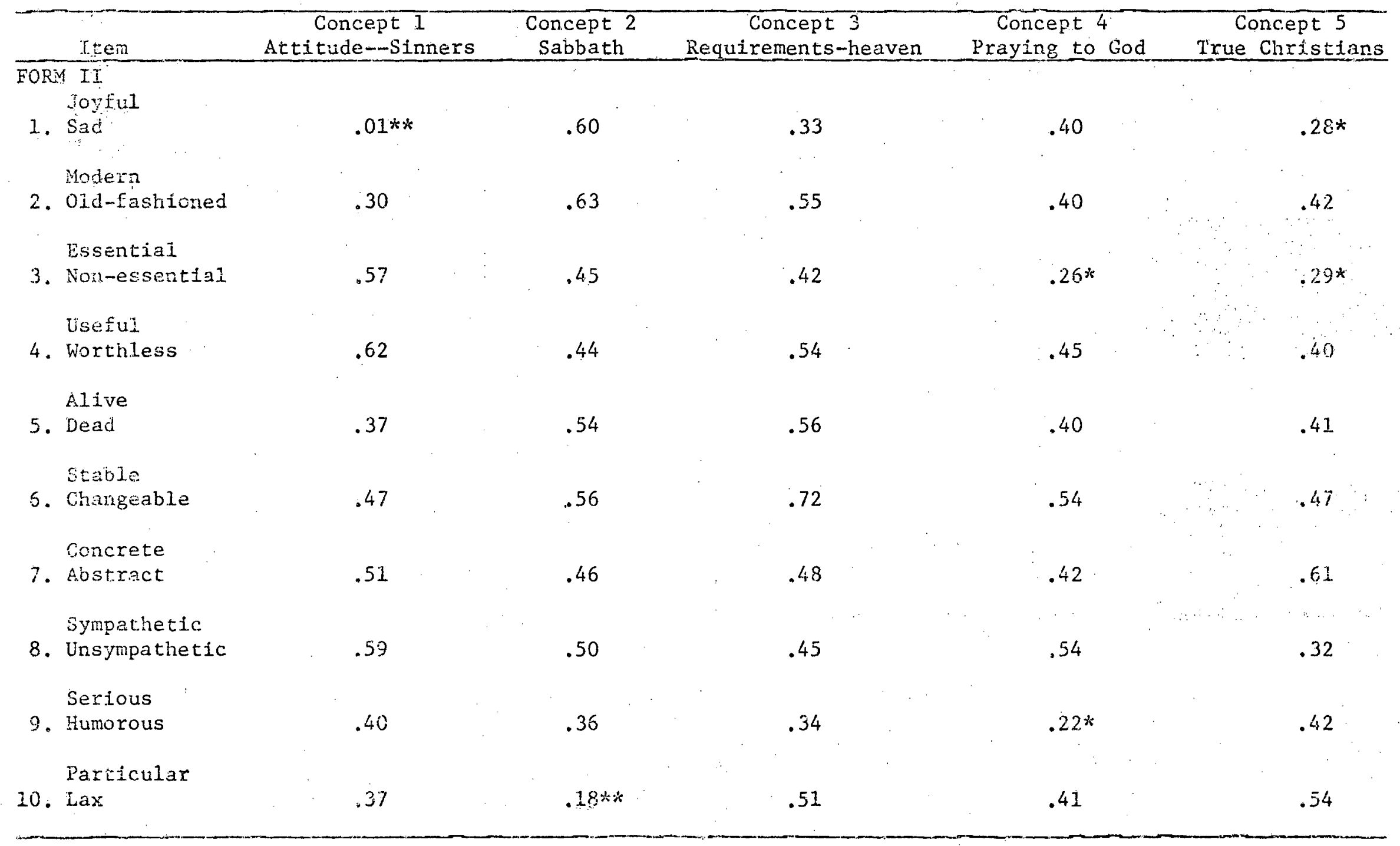

* Tndtcates zow or cuestanable point multiserials

** Indicates poor point multisertals 
TABIE 2

MEAN SCORE, STANDARD DEVIATION, AND RELIABILITY COEFFICIENT LLPHA FOR FIVE CONCEPTS - ATTITUDE

SCALE - FORMS I AND II

\begin{tabular}{|c|c|c|c|c|c|c|}
\hline \multirow{2}{*}{ CONCEPT } & \multicolumn{2}{|c|}{ MEAN SCORE } & \multicolumn{2}{|c|}{ S. DEVIATION } & \multicolumn{2}{|c|}{$\begin{array}{l}\text { RELIABILITY COA } \\
\text { EFFICIENT ALPHA }\end{array}$} \\
\hline & Forn 1 & Form 2 & Form 1 & Form 2 & Form 1 & Form 2 \\
\hline $\begin{array}{l}\text { 1. God's attitude } \\
\text { toward sinners }\end{array}$ & 35 & 38.5 & 6.5 & 4.7 & .76 & .50 \\
\hline 2. God's Sabbath & 37.8 & 39.9 . & 6.2 & 5.3 & .79 & .67 \\
\hline $\begin{array}{l}\text { 3. Requirements } \\
\text { for heaver }\end{array}$ & 37.4 & 40.1 & 5.0 & 5.5 & .60 & .72 \\
\hline 4. Praying to God & 40.5 & 40.7 & 6.0 & 4.9 & .80 & .63 \\
\hline 5. True Christians & 40.9 & 41.1 & 5.3 & 5.0 & .72 & .65 \\
\hline
\end{tabular}


A second item analysis was then done using the thirteen remaining bipolar adjective pairs and treating each form as one test. This meant that the results would indicate how each item was measuring in the total test i.e. all five concepts put together as a whole, rather than on each individual concept separately.

Thus, in this item analysis there were two tests (Forms I and II) with thitty-five and thirty ilems in each respectively. However, since each concept uses the same adjective pairs each item was repeated five times. For example, item one on Form I was the adjective pair "exciting-boring." Because it was used for each concept, every eighth item in the item analysis was "excitingboring." Every bipolar adjective pair would have five point multiserials as the result of the analysis.

Table 3 indicates the point multiserials for the thirteen items. (It nust be remembered that each item was repeated five times, once for each concept.)

The point multiserials on this analysis are somewhat lower than those for the same items on the first item analysis. This is easily understood when one realizes that each item on the first analysis was compared with the nine other items for each of the five concets separately. In the second item analysis, however, each item was compared with the test total for all five concepts. This, of course was a much larger group for correlation and consequentiy the point multiserials are somewhat jower. This time, therefore, an item with a point multiserial below twenty was considered questionable and those with a point multiserial below fifteen were considered poor. 
T'ABLE 3

POTNT MULTISERIAL RATINGS OF EACH OF THIRTEEN ITEMS

ON THE TWO FORMS OF THE ATTITUDE SCALE

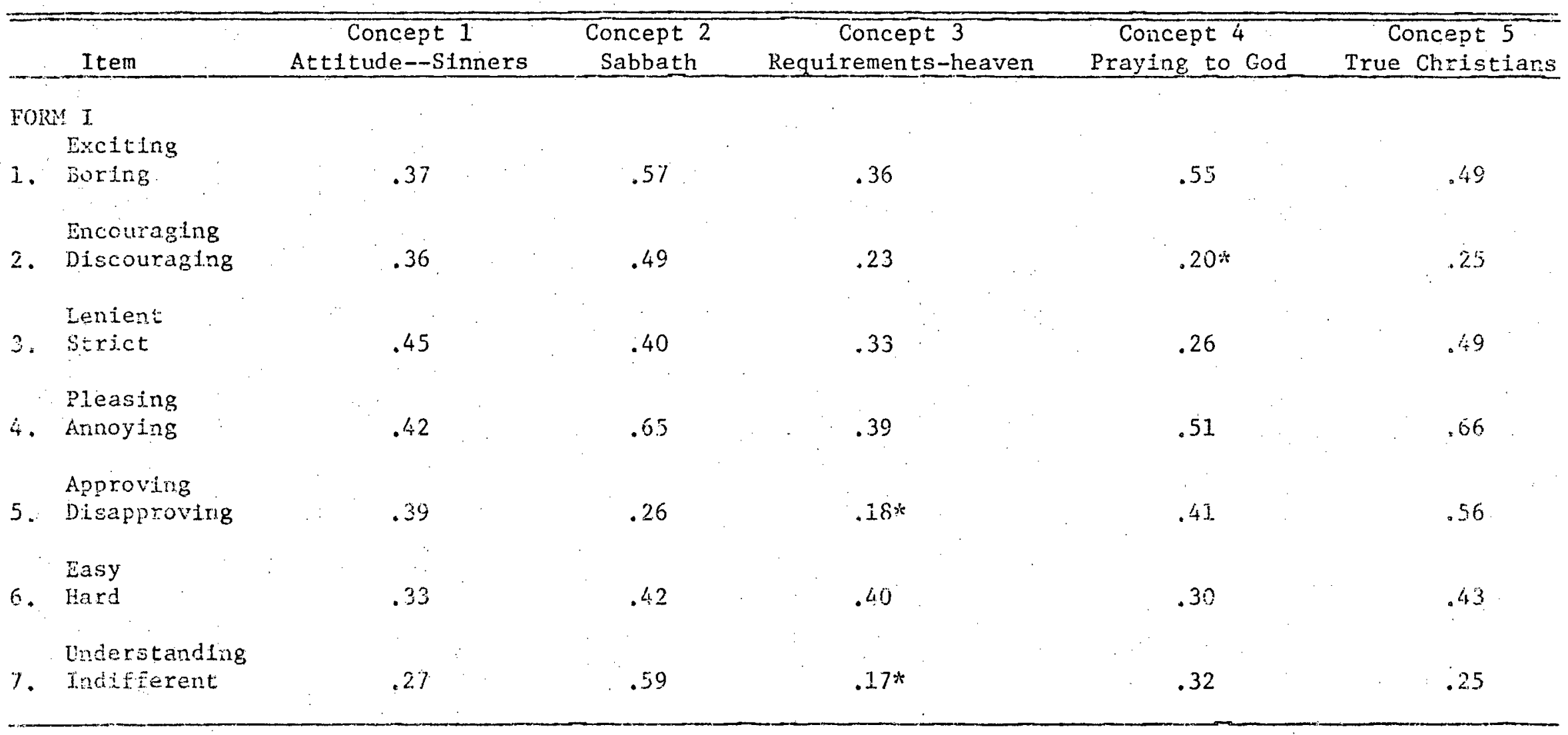


TABLE 3 (CONTINUED)

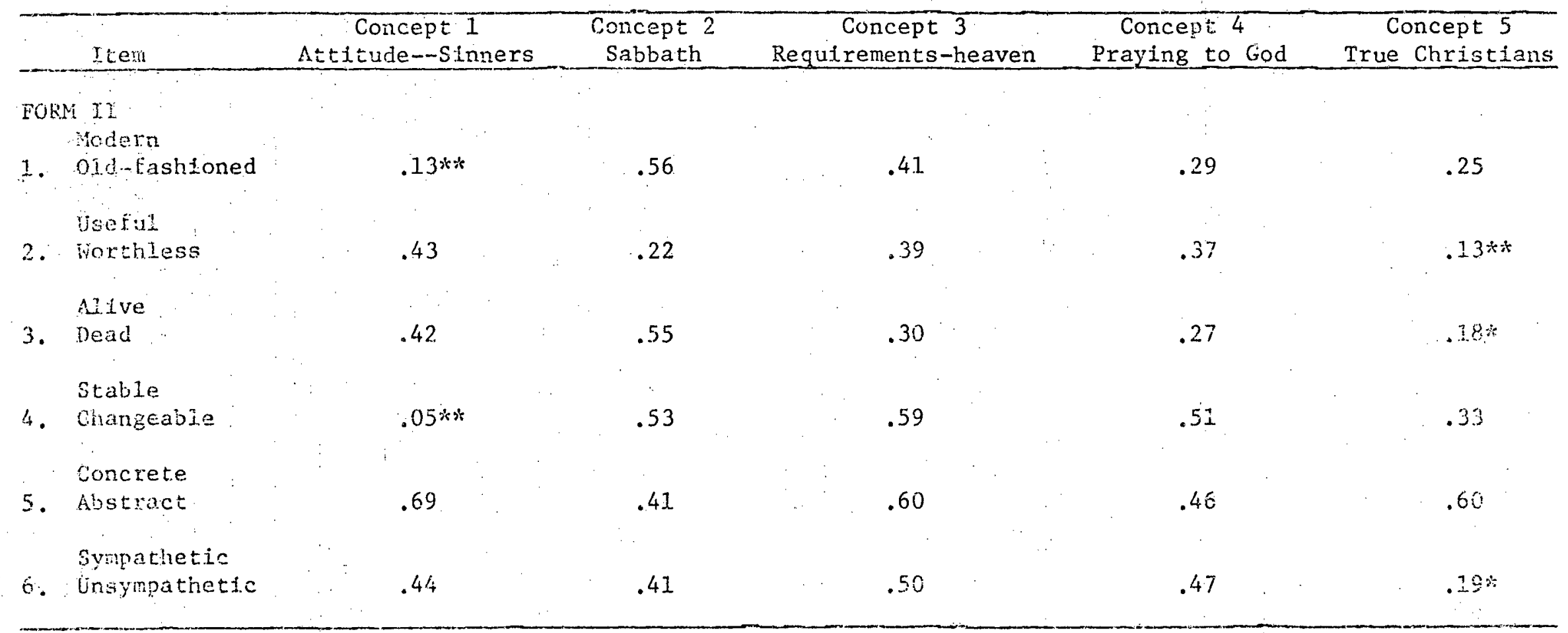

* Questionable polnt multiserials

** Low point multiserials 
It wilj. be noted from the table that some items nad a questionable point multiserial on one concept. No item, however, had more than one.

Three items had poor point multiserials--Nodern-0ld-Fashioned; useful-worthless; and stable-changeable." Stable-changeatle had the lowest point multiserial of any item (.05). However, the other point. multiserials for that item were all strong.

Table 4 shows the standard deviation, mean score, and reliability coefficient alpha for the second item analysis.

\section{TABLE 4}

STANDARD DEVIATION, MEAN SCORE, AND RELIABITITY

COEFEICIENT ALPHA FOR THIRTEEN BIPOLAR

ADJECTIVE PAIRS ON SECOND ITEM ANALYSIS

\begin{tabular}{lcc}
\hline & FORM I $(\mathrm{N}=35)$ & FORM II $(\mathrm{N}=30)$ \\
\hline Mean & 132.29 & 116.59 \\
Maximum Score Possibie & 175 & 150 \\
Standard Deviation & 16.14 & 13.94 \\
Reliability Coefficient Alpha & .857 & .842 \\
\hline
\end{tabular}

Since no icem had more than one questionable or low multiserial and since it takes a minimum of time for students to make judgments and mark responses when taking the test; the final instrument consisted of inve concepts each to be judged by the thirteen items used on the second item analysis. 


\section{Format}

Form of Concept Statement

Iwo ways of stating the concept were explored. One way stated the concept in the form of an open-end sentence, eg. "God's attitude toward sinners is.. ." The other way was a title type of concept eg., "God--His attitude toward sinners."

After the five concepts were chosen; two were used in a small pilot study using ten fifth and sixth grade students from the Andrews University Laboratory Schoel. The instrument was administered individually and five students dealt with the concepts as open-end sentences and fjue had the concepts written as titles. The siudents were randomly selected, i.e. pencil dropped on roster for those grades. There was no apparent difference in degree of understanding between the two methods of stating the concept. Because the openend statement seemed to act as a springboard and thought-starter, it was chosen by the writer as the form in which the concepts would be stated.

Wuinoer of Possible Responses

Osgood originally designed the semantic differential scale to be a seven step evaluation. This would mean that between each adjective of the bi-polar pair would be seven blanks on which the student coujd respond. In his book Measurement of Meaning (195\%, p. 85) Osgood states that while he believes seven possible responses is best, for school children a five point scale seems to work better. Some erucators interviewed, however, felt a three point scale would be most effective. 
To solve this dilemma ten fifth and sixth grade students at the Cedarvale Seventh-day Adventist School in Kansas City, Missouri were administered the instrument on an individual basis using only three concepts. Again the students were randomly selected and haif used the five point response scale and half used the three point scale. There was no visible difference in the facility with which each group registered their response. The group using the three Foint scale all thought they could be more accurate if there was a place to record a "kind of" and "sort of" response. The students all offered this observation on their own and none were asked if they thought the five point scale would be better. Consequently, the five point scale was chosen.

Type of Test - Group or Individual

The next major item to be considered in the deveiopment of the instrument was whether the scale would be administered individually to students or whether it would serve its best purposes administered to the subjects in a group setting.

To determine this, the test was administered both ways. It was first administered individually to fifth and sixth grade students at the Andrews University Laboratory School. The students, who were randomly seiected, were told that they were not to sign their names but merely mark their responses. Two observations were noted; The student often gianced up to see $\dot{i} \hat{i}$ he was being watched and (2) if the student saw someone looking at him, he stopped his work and waited. 
Later, the instrument was adninistered to ten fifth and sixth grade students in a group setting. Again, all were instructed not to sign their rames, to respond honestly to all items and were assured that no one wonld know how they responded. The students who began working immediately seemed comparatively unconcerned about whether or not anyone watched them.

Because greater anonymity seemed possible in the group situation and because it seemed to give the students a greater degree of security and confidence, it was decided that the instrument should be administered as a group test. 
CHAPTER V

RELIABILITY AND VALIDITY

Reliability

Factor Analysis of Concepts

Before an instrument can be used vith confidence it must be tested for stabiity and consistency. One way of doing this is to seek for functional unities within the test itsejf. If factors can be found which can be said to account for the variance, the instrument can be deemed stable.

A factor analysis, therefore, was done on the five concepts with the ten evaluative scales which comprised the originaj. Form I and Form 2 of the test. A principal components factor analysis with a. varinax rotation was used. Since there were only five concepts, it was arbitrarily decided to extract two factors only.

In the varimax rotation the loadings of each concept and each extracted factor are plotted on a matrix. These loadings are then rotated on the matrix to identify more clearly the relationship between each factor and concept, with the idea that the concept should be heavily loaced on one factor and not so heavily loaded on the other.

The resuits of the factor analysis after the varimax rotation are shown in Tables 5 and 6 .

The tables snow that all the concepts with the possible exception of concept 3 on form I are moxe heavily loaded on one 
TABLE 5

FACTOR ANAIYYSIS-FORM I

\begin{tabular}{|c|c|c|c|}
\hline Concept & $\begin{array}{c}\text { Factor } \\
1\end{array}$ & $\begin{array}{c}\text { Factor } \\
2\end{array}$ & $h^{2}$ \\
\hline 1. Attitude to simners & .119 & .660 & .450 \\
\hline 2. Sabbath & .747 & .321 & .661 \\
\hline 3. Fraying to God & .231 & .392 & .207 \\
\hline 4. Requirements for heaven & .352 & .034 & .125 \\
\hline 5. True Christians & .647 & .068 & .423 \\
\hline
\end{tabular}

TABLE 6

FACTOR ANALYSIS-FORM II

\begin{tabular}{lccc} 
& Factor & Factor & \\
Concept & 1 & 2 & $\mathrm{~h}^{2}$ \\
\hline 1. Attitude toward sinners & .102 & .468 & .230 \\
2. Sabbath & .707 & .390 & .652 \\
3. Praying to God & .158 & .404 & .188 \\
4. Requirements for heaven & .721 & .207 & .562 \\
5. True Christians & .631 & .067 & .380 \\
\hline
\end{tabular}


factor than on the other. The proportion of total variance of the concept which is accounted. For by the two factors is shown in the column, $n^{2}$.

The factor patteris on the two analyses was then compared using Tucker's coefficient of congruence (Harman, 1967, pp..269-270). Table 7 shows this comparison and indicates that the concepts are quite stable with regard to items. Factor I on Form I is closely reiated to factor 1 on Form II and factor 2 on Form I is closely related to factor 2 on Form II. The relationship between other factors is minimal. This indicates stability of factor loadings of the five concepts over the two different scales.

TABLE 7

COEFFICIENT OF CONGRUENCE

FORM I AND FORM II

FIRST FACTOR ANALYSIS

Form I

Factor 1

Factor 2

Form II

Factor 1

.949

.423

Factor 2

.570

.934

Another factor anajysis was then done using the thirteen scales ( 7 on form $I$ and $6 \mathrm{cn}$ form $I I$ ) for each of the five concepts. As before a principal components factor analysis with varimax rotation was used.

Iables 8 and 9 show the results of this analysis for each fort; this time using 13 seales instead of 20 . 
TABLE 8

EACTOR ANALYSYS- FORH I

7 SCALES

\begin{tabular}{lccc}
\hline Concept & $\begin{array}{c}\text { Factor } \\
1\end{array}$ & $\begin{array}{c}\text { Factor } \\
2\end{array}$ & $\mathrm{~h}^{2}$ \\
\hline 1. Attitude to sinners & -.044 & .837 & .703 \\
2. Sabbath & .609 & .560 & .685 \\
3. Praying to God & .876 &. .041 & .769 \\
4. Requirements for heaven & .551 & .237 & .480 \\
5. True Christians & .423 & .680 & .640 \\
\hline
\end{tabular}

TABLE 9

FACTOR ANALYSIS--FORM II

6 SCALES

\begin{tabular}{lccc}
\hline Concept & $\begin{array}{c}\text { Factor } \\
1\end{array}$ & $\begin{array}{c}\text { Facto } \\
2\end{array}$ & $\mathrm{~h}^{2}$ \\
\hline 1. Attitude to sinners & .414 & .645 & .587 \\
2. Sabbath & .880 & .209 & .813 \\
3. Fraying to Cod & .747 & .453 & .763 \\
4. Requirements for heaven & .811 & .192 & .694 \\
5. True Christians & .145 & .893 & .891 \\
\hline
\end{tabular}

$\Sigma h^{2}=3.753$ 
As in the first factor analysis, the tables indicate that the concepts show greater loadings on ore factor than on the other. A comparison of Tables 8 and 9 with Tables 5 and 6 shows that the total. $h^{2}$ value is very much higher on the last factor analyses. The removal. of the weak items resulted in a higher proportion of variance being accounted for by the two factors.

The factor pattems on the two analyses were again compared by the use of Tucker's coefficient of congruence (Harman, 1967, pp. 269-270). Table 10 shows this comparison.

TABI,E 10

COEFFICIENT OF CONGRUENCE

FORM I AND FORM II

SECOND FACTOR ANALYSIS

Form I

Factor 1

Factor 2

Factor 1

.903

.601

Form II

Factor 2

.618

.851.

Again the concepts seemed to be quite stable with regard to the thirteen scales usea.

Coefirient Alpina and Test-Retest Reliability

To detemine the internal consistency of the instrument the coefficient aipha reliability was computed for each admiristration of the test. The first adninistration (See Chapter 4 ) used the origind twenty sets of adjective pairs. Each concept, however, was 
considered separately and so there were Fue coefficients for each form or ten in a11. These coefficients ranged from .7963 tc .5983 with a median of .7642 on Form $I$ and from .7165 to .5017 with a median of .6627 on Form II.

The second administration used the finally selected thirteen adjective pairs (seven in Form $I$ and six in form $I I$ ) and all five concepis were put together as a whole. Therefore, there were two coefficients for that instance. These coefficients were .8572 and .8419.

Lastly the test was administered twice to the same group of students and the coefficient alpha was determined for each administration. The coefficient alpha for the first test was .8957 and .9128 for the retest.

The instrument in its final form (Appendix C) was administered to sixty-six fifth and sixth grade students in the Village Seventhday Adventist school Berrien Springs, Michigan. Approximately four weeks later the same instrument was again administered to the same students. The reliability coefficient of the two test scores was .77 .

\section{Validity}

As there is no reliable criterion measure which could be used in calculeting concurrent validity, a statement of face vaiidity seened to be most desirable. Consequentry, a comittee of experis was chosen to examine the instrument, evaluate it and rate it as to its apparent validity. 
The six experts chosen were educators and theologians employed by the Seventh-day Adventist Church: Four had their doctoral degree in either education or theology and two, administrators in the field of elementary supervision, had master's degrees.

Those serving on the committee were asked to do two things: 1) choose from the original list of twenty adjective pairs (see Appendix E) thirteen which in their opinion would most accurately measure the concepts as listed, and 2) evaluate the instrument careiully and rate it on the rating scale (Appendix F).

Two experts on the committee felt that asking them to choose thirteen adjectives from a list of twenty was, in essence, checking their attitudes toward God rather than the validity of the instrument. The results of this exercise, however, were quite interesting and are included in Table 11.

It is interesting to note that three of the final thirteen adjective pairs were chosen by all six experts. None of the final. thirteen was chosen by less than three members of the committee.

Two other observations should be made, however, namely, 1) the adjective pair Willing-Unwilling was chosen by all six experts but statistically was ruled out as being a weak item, and 2) no one chose the adjective pair Serious-Humorous, and only one chose the adjective pair Particular-Lax. Both of which were judged reak by the statistical analysis.

Responses from the committee were very encouraging. Of the six nembers, four rated the instrument as "rather" supexior and two 
TABLE 11

FREQUENCY OF ADJECTIVE SELECTION BY

COMITTEE OF EXFERTS

Adjective Pair

Frequency of Selection

*Exciting-Boring

6

Watchful-Unconcerned

3

*Encouraging-Discouraging

5

*Lenient-Strict

5

*Pleasing-Annoying

5

*Approving-Disapproving

4

Hot-Co1d

3

*Easy-Hard

3

Wi1ling-Unwilling

6

*Understanding-Indifferent

6

Joyful-Sad

5

*Modern-01d-fashioned

3

Essential-Unnecessary

3

*Useful-Worthless

3

*A1ive-Dead

3

*Stable-Changeable

*Concrete-Abstract $\quad 3$

*Sympathetic-Unsympathetic $\quad 6$

Serious-Hunorous 0

Particular-Lax 1

\#Indicates the 13 appearing on the firal instrument. 
rated it as superio: as to its validity. Three experts consicered the directions to the students about average while the other three thought they were "rather" superior.

Several very valuable suggestions were made concerning the instruments and are listed here because of thejr pertinency:

1. Most comments made concerned the directions to the student: One expert suggested that, instead of blanks between the bipolar adjective pairs, that the numbers $1-5$ be placer there and that the students simply circle the number. One would be the most posjtive response and five the most negative.

2. Another suggestion concerning the directions to the student was that a sample similar to the following be given so the student could easily see the meaning of each space betweeri the adjective pairs.

Example:

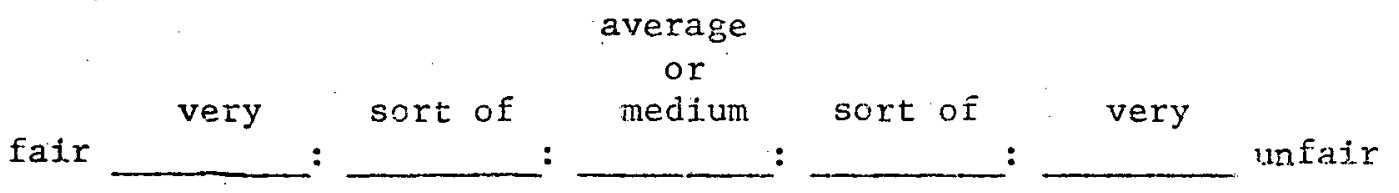

3. Four of the experts felt that the word "concepts" was a bit difficult for upper elementary students and suggested that the word "idea" be substituted in the directions to the students.

4. One individual suggested that the children might confuse the personages "God the Father" and "Jesus" and suggested that after an interval of time the instrument be administered again and this time the attitudes toward jesus be measured. 
CHAPTER VI

PIİOT STUDY

The second objective of the study was, as stated in Chapter One, to test the usefulness of the instrument in a small pilot study. Froin the group of sixty-six students used for the test-retest reliability study, twenty-three were randomly selected for use in the pilot study. Two teachers were also asked to respond to the instrument. Eleven of the students came from the classroon of Teacher A and twelve from the classroom of Teacher $B$. The responses of the twentythree students and their teachers were used in the pilot study.

\section{Comparison of Class Mean and Teacher Mean}

For each student the instrument yielded thirteen scores relative to each concept. The maan of these thirteen scores was obtained for each of the five concepts for each student. A mean score for each class on each concept was then obtained and was compared to the teacher's concept means for that class under the null hypothesis that the ciass mean is equal to the given teachex mean. Tabies 12 and 13 stiow these means and the probability of the difference of the class mean from the teacher mean on each concept. 
TABLE 12

TEACHER AND CLASS MEAN FOR EACH CONCEPT TEACHER A

\begin{tabular}{|c|c|c|c|c|c|}
\hline & $\begin{array}{c}\text { Concept } \\
1\end{array}$ & $\begin{array}{c}\text { Concept } \\
2\end{array}$ & $\begin{array}{c}\text { Concept } \\
3\end{array}$ & $\begin{array}{c}\text { Concept } \\
4\end{array}$ & $\begin{array}{c}\text { Concept } \\
5\end{array}$ \\
\hline Teacher Mean & 4.4 & 4.7 & 5.0 & 4.7 & 4.8 \\
\hline Class Mean & 3.6 & 3.7 & 4.0 & 3.8 & 4.1 \\
\hline $\mathrm{p}$ & $<.05$ & $<.01$ & $<.01$ & $<.01$ & $<.01$ \\
\hline
\end{tabular}

TABLE 13

TEACHER AND CLASS MEAN FOR EACH CONCEPT TEACHER B

\begin{tabular}{lccccc}
\hline & $\begin{array}{c}\text { Concept } \\
1\end{array}$ & 2 & $\begin{array}{c}\text { Concept } \\
\text { Concept }\end{array}$ & $\begin{array}{c}\text { Concept } \\
4\end{array}$ & $\begin{array}{c}\text { Concept } \\
5\end{array}$ \\
\hline Teacher Mean & 3.8 & 4.1 & 4.2 & 3.8 & 4.5 \\
Class Mean & 3.3 & 3.7 & 3.9 & 3.8 & 3.8 \\
D & $<.01$ & $<.05$ & $<.05$ & -0.05 & $<.01$
\end{tabular}


As the tables incicase in all. inctances except one the mean attitude of the students was different from the teacher mean beyond the .05 level of significance. The only exception was on concept four "God's Requirements for Heaven are.. . : in Table 13. In this instance the mean of the rancom: sample of the students and Teacher $B$ were identical. From this analysis it would seem that in most instances these students hold significanty different attitudes toward God from those held by theix teachers.

\section{Construction and Comparison of D Matrices}

\section{Corstruction of D Matrices}

A semantic differential scale measures semantic or meaning space. If two concepts are closely related in senantic space, they hold similar meanings for the individual making the judgments. An adequate method of comparing the attitudes of teacher and students would be to measure the distance (D) between any two concepts. To compute $D$ the differences of the assigned values for the scales of one concept and another were squared, added together, and the square root of the sum was extracted. For example, Table 14 shows the scores for a hypothetical student, ising five scores for each of two concepts.

To find $D$ for the above sample one simply uses the formula,

$$
\begin{aligned}
D_{A B} & =\sqrt{(5-3)^{2}+(4-3)^{2}+(1-2)^{2}+(4-1)^{2}+(2-1)^{2}} \\
& =\sqrt{16} \\
& =4
\end{aligned}
$$


TABLE 14

SCORES FOR A HYPOTHETIOA SIUDENT

5 SCALES AND 2 CONCEPTS

\begin{tabular}{lcc}
\hline Scales & Concept A & Concept B \\
\hline 1 & 5 & 3 \\
2 & 4 & 3 \\
3 & 1 & 2 \\
4 & 4 & 1 \\
5 & 2 & 1 \\
\hline
\end{tabular}

This was done for each concept and the results were plotted on a matrix for each individual used in the pilot study. The minumum $D$ or $\mathrm{D}_{\min }$ for any student for the thirteen scaies would obviously be zero. This would mean that the student rated each concept in precisely the same way on the scales. The maximum $D$ would be the square root of $(4)^{2} \times 13$ (a distance of 4 between each pair of scales times 13 scales). $D_{\max }$ then would equal 14.42. Tables 15 and 16 show matrices for Teacher $B$ and one student randomly selected. The remaining matrices are in the appendix.

\section{Comparison by Observation}

Although the $D$ matrix is subject to several types of analysis the basis of them all is the search for clusters of meaning. The smaller the $D$ between any two ccncepts the closer the relationship of meaning between them. Conversely, the higher the D the greater 
TABLE 15

D MARIX - TEACHER B

\begin{tabular}{cccccc}
\hline Concept & 1 & 2 & 3 & 4 & 5 \\
\hline 1 & 0 & 5.196 & 5.292 & 4 & 5.659 \\
2 & 5.196 & 0 & 3.742 & 3 & 5.568 \\
3 & 5.292 & 3.742 & 0 & 4.899 & 5.477 \\
4 & 4 & 3 & 4.899 & 0 & 5.745 \\
5 & 5.659 & 5.568 & 5.477 & 5.745 & 0 \\
\hline
\end{tabular}

TABLE 16

D MATRIX -- STUDENT 257

\begin{tabular}{cccccc}
\hline Concept & 1 & 2 & 3 & 4 & 5 \\
\hline 1 & 0 & 7.071 & 6.865 & 5.292 & 7.071 \\
2 & 7.071 & 0 & 1 & 3.742 & 0 \\
3 & 6.856 & 1 & 0 & 3.606 & 1 \\
4 & 5.292 & 3.742 & 3.605 & 0 & 3.742 \\
5 & 7.071 & 0 & 1 & 3.742 & 0 \\
\hline
\end{tabular}


the distances between meanings. Using Table 15 it is possible to define clusters of concepts by comparing the Ds in each row. For example, in row two concets three and four seem to be quite closely related to concept two; the D values being 3.742 and 4 . Before a definite judgment can be made, however, it is necessary to see if concept three relates closely to concept four. In.this instance it does with a $D$ of 4.899 . It can be said, therefore, that concepts two, three, and four form a cluster and hold similar meanings for Teacher B. In other words, the Sabbath, God's recuirements for Heaven, and prayer have similar meanings for Teacher $B$.

In Table 16 concept two appears to be closely related to concepts three, four, and five. In fact, there is no difference in meaning between concept two and concept five. A comparison of the Ds between concepts three:four and three:five shows close relationship between these concepts. Concept four is also closely related to concept five. In this instance, therefore, concepts two, three, four, and five form a cluster and hold similar meanings for Student 257. For this student, concept one seems to be quite different from the cluster of the other four concepts.

The two natrices can also be compared with each other to determine if similar clusters of meaning exist for both Teacher $B$ and Student 257. Concepts tios, three and four formed a cluster of meaning in the matrix for Teacher $B$. Those same three concepts with the addition of concept five formed a cluster in the matrix for Stident 257. Therefore, both the teacher and student see the same clusters of concepts às belonging together. 
Comparison by Ranking

The Ds of the teachers and students were analyzed in yet another way. After ranking the Ds for eech student, Kendali's coefficient of concordance between rankings was computed. For the eleven students of Teacher A the coefficient of concordance was .163 which is not statistically significint. This means that the relationship existing between the Ds of the students of Teacher A is not significant and therefore, the students are not ranking then in the same way.

The same analysis was done for the twelve students selected from Teacher B's classroom. The coefficiert of concordance vas .219 which was significant at the .01 level. It seems, therefore, that a closer relationship exists between the attitudes of the students of Teacher B than exjsts between the attitudes of the sturents of Teacher A.

Comparison by Pearson Product Moment

Because the twelve students of Teacher $B$ appear to have simjlar $D$ matrices, the median value of each $D$ for this group of students was obtained. The Pearson product monert correlation coefficient was obtained between the distribution of median $D$ vaiues and the teacher's i valies. The resulting coefficient was 401 , which is not statisticaily significant. A value of .549 was required for significance at the 05 Leve1. 
CHAPTER VII

SUMLARY, CONCLUSIONS AND MMPLICATIONS

\section{Sunnary}

The two objectives of the study weite to: 1) develop an instrument which rould measure students' attitudes toward God, and 2) to use the instrument in a smail pilot study to test its usefulness.

The first objective was met by developing an instrument patterned after the format of Osgood's Semantic Differential. whici. measured semantic or meaning space. His" subjects made judgments by rating certain concepts on the basis of a set of scales which were pairs of bipolar adjectives. Each concept was judged by the same set of scales.

Using this pattern five concepts vere chosen for the instrument. This choice was based upon the concept's relevance for boys and girls and because they were selected from a list of concepts by at least three members of a specially chosen comittee of eaucationists and theologians at Andrews University, Berrien Sorings, Michigan. This same conmittee selected fron an extensive 1ist the thenty pairs of bifolar adjectives used in the initial stages of the zesearch.

$$
\text { originally the instrument was in two forms wilich were }
$$

administered to approximately ninety-seven fifti and sixth grade 
students at the Andrews Iniversity Laboratory School: Each form contained the same five concepts but the scales by which the concepts were judged were different for each forth. Ten scales or twenty sets of bipolar adjectives were used for each test. An item analysis was carried out in an effort to eliminate those scales which were non-discriminatory. Each concept was treated as a separate test in the analysis and any bipolar adjective pair with a point multiserial below thirty was considered weak. As a result seven of the twenty original pairs were eliminated.

The remaining thirteen scales were submitted to another item analysis. This time, however, each form rather than each concept was treated as a separate test. This analysis revealed that all thirteen adjective pairs vere comparatively strong. The final instrument containea five concepts, each of which was evaluated by the same thirteen bipolar adjective pairs.

A factor analysis, using a varimax rotation, yielded two factors which accounted for an average of .75 of the total variance on each concept. Use of Tucker's coefficient of congruence indicated a stability of factor pattern over different scales.

Two methods of determining reliability were used. The first, coefficient alpha reliability, measured the internal consistency of the instrument. On the initial administration of the test the coefficient alpha reliability was computed for each concept on each of the two forms, yjelding ten in all. On Form I the coefficient a1pha ranged from .7963 to .5983 , with a median of .7642 . On Form II 
the coefficient alpha 1 iaiged from .7165 to .5017, with a median of .6627 . On the last adninistration of the instrument the coefficient alpha reliability was .9128 . This indicates that the instrument was greatiy strengthened by the removal of the weak scales.

A test-retest reliability study was also conducted. This time the instrument was administered to sixty-six fifth and sixth grade students at the Village Seventh-day Adventist School in Berrien Springs, Michigan. Approximately four weeks later the same test was again administered to the same students and a .77 testretest reliability resulted.

Because there were no criteria upon which to base a study of concurrent validity, a statement of face validity was obtained. A panel of six individuals, experts in the field of theology and education, was chosen. Each individual was asked to evaluate the instrument and judge whether or not it appeared to be a valid instrument for the neasurement of children's attitudes about God. This committee of experts juaged the instrument to be valid for the purpose intended.

A small pilot study involving twenty-three of the sixty-six chilidren used in the test-retest study was conducted. Their teachers also participated in the study and various statistical procedures were used to analyze and compare the data obtained.

\section{Conclusions:}

As a result of the study, three conclusions were reached. They are: 
1. It is possible to develop an alequate instrument which will measure children's attitudes toward Cod.

2. The attitude scale can be administered by the average classrom teacher. However, establishment of norms would make the interpretation of the data more meaningful.

3. The pilot study clearly indicates the usefuiness of the instrument but provides no clue to the source of or reason for the children's attitudes.

\section{Impications for Further Study}

Implications for further study and research are numerous. Included here are some suggestions for further research in the area of children's attitudes about God.

1. The instrument in its present form is limited in its use by educators. The development of norms, therefore, is of prime importance in making the instrument more usable.

2. No attempt was made in this study to determine the causes or origin of the attitudes held. A causal study into the reasons for the attitudes would be valuable. Such a study wculd, of necessity, include the honie and parents as well as the school and teacher.

3. Using a far greater number of teachers, a more exhaustive study should be conducted, following the design of the pilot study as outlined in Chapter Six.

While the instrument has been proven to be both reliable and valid, there are a few precautions that shouid be noted by persons using it. These precautions are: 
1. Although a high raw score is indicative of a somewhat positive attitude toward God, and a low score a somewhat negative attitude toward God, the user must exert extreme caution not to "label" one student a "good" Christian and another a "bad" Christian on the basis of their responses.

2. The instrument in no way attempts to explain the causes of the attitudes revealed.

3. Norms for the instrument are not presently available. The researcher therefore should not attempt to make judgments hastily without using adequate statistical procedures:

The instrument has been developed. It is both reliable and valid for the purpose for which it was developed. The possibilities for its use are numerous. U1timately; hovever, the instrument would be of greatest value if it were administered widely throughout the Seventh-day Adventist school system to evaluate how successfully positive attitudes toward God are being developed in the lives of the students. The results of such a project could be used to modify or strengthen instruction in this area, thereby, increasing the effectiveness of the Seventh-day Adventist elementary school system. 
B I B I I O G R A P H Y 
Avent, Joseph Emery. The Excellent Teacher. Knoxville, Kentucky: Author, 1931.

Bernard, Harold W. Psychology of Learning and Teaching. New York: MCGraw-Hi11 BCok Company, 1965.

Boynton, P. L., F. Dugger, and M. Turner. "The Emotional Stability of Teachers and Pupils," Journal of Juvenile Research, 1934, $18,223-2.32$.

Brown, Kenreth Irving. Not Minds Alone. Evanston, I11.: Harper Brothers, 1954 .

Chansky, Norman M. "The Attitudes Students Assign to Teachers," Journal of Educational Psychology, 1953, 49, 13-16.

Coster, John K. "Attitudes Toward School of High SchooI Pupiis from Three Income Levels," Journals of Educationa1 Psychology, $1958,49,61-65$.

Dinkmeyer, Don C. Child Development, The Emerging Self. Englewood Cliffs, New Jersey: Prentice Ha11, 1965.

Fleming, Charlotte M. Teaching: A Psychological Analysis. Lordon: Methune and Co. Ltd., 1958.

Frymeier, Jack R. "Teaching the Young to Love," National Elementary Principal, 1969, 49, 19-25.

Gick, Oren. "Sixth Graders' Attitudes Toward School and Interpersonal Conditions in the Classroom," Journal of Experimental Education, $1970,38,17-22$.

Harvey, Philip J. "Teacher Attitudes: Subject Matter and Human Beings," Educationa1 Leadership, 1970, April, 586-691.

Harman, H. Modern Factor Analysis. Ürbana, Chicago, and London: University of Illincis Press, 1967.

Hartshorne, Hughs and May, Mark A. Studies in Deceit. New York: Macrilian, 1928.

Heglund, Martin. Christianity in Education. Minneapolis: Augsburg Publishing House, 4954. 
Keriinger, Fred N. Foundations of Behavioral Research. New York: Holt, Rinehart and Winston, Inc., 1964.

LeFevre, Perry. The Christian Teacher. Scuth Nashville, Tennessee: Abingdon Press, 1958.

Luckman, Lloyd D. (Chrm), California Comission for the Study of Education. Reveloping Moral and Spiritual Values in the Schools. Falo Alto: Fearon, 1957.

Michigan Department of Education. Education in Moral. Values in Michigan: A Feport on a Survey and Discussion of Implications for Educators. Lansing, Mich.: Michigan Department of Education, 1.968.

Neale, Daniel C.; Gill, Noel, and Tismer, Earner. "Relationship Between Attitudes Toward School Subjects and School Achievement." Journal of Educational Research, 1970, 53, 232-237.

Niblett, W. R. Moral-Education in a Changing Society. London: Faber and Faber, 1964 .

Osgood, Charles E.; George J. Suci and Percy H. Tannenbaum. The Measurement of Meaning. Urbana, Chicago, and London: University of IIIjnois Press, 1957.

Phenix, Philip is. Education and the Worship of God. Philadelphia: Westminster Press, 1965.

Richmond, Bert D. and William F. White. "Sociometric Predictors of the Self Concept Among Fifth and Sixth Grade Children," Journal of Educational Research. 1971, 64, 425-429.

Ryans, David G. Characteristics of Teachers. Washington: American Council on Education, 1960.

Scarf, Eugeria. "The lise of Semantic Differential in Measuring Attitudes of Elenentary School Children Toward Mathematics," School Science and Mathematics, 1971, 71, 641-649.

Torrance, $\mathrm{E}$. Faul and Mason, Raigh. "Instructcr Effort to Influence: An Fxperimental Evaluation of Six Approaches," Journal of Educational Psychology, 1958, 49, 211-217.

Vroom, Victor F. "Projection, Negation and the Self Concept," Human Relatiors, $1959,12,335-344$.

White, Ellen G. Education. Mountain View: Pacific Press Publishing Association, 1903. 
- Testimonies fot the Church, Voiume v. Mountain View: Pacific Press Plojehing Company.

- Fundamentals of Christian Education. Nashville:

Southern Pubiishing Association, 1923. 



\section{APPENDIX A}

FORYI I

ORICINAL INSTRUMENT

Dear Student:

The purpose of this study is to measure what you think about cod. In taking this test, please nake your choice on the basis of what you think and not on what someone wants you to think. No one will know what you have written, so please be frank in your answers.

On each page of this booklet you will find a different concept to be judged and beneath it a set of scales. You are to rate the concept on each of these scales in order. That is once you have finished a concept you are not to return to it, nor are you to work ahead before you finish a concept.

Here is how you are to do these scales: If you feel that the concept at the top of the page is very closely related to one end of the scale, you should place your check-mark as follows:

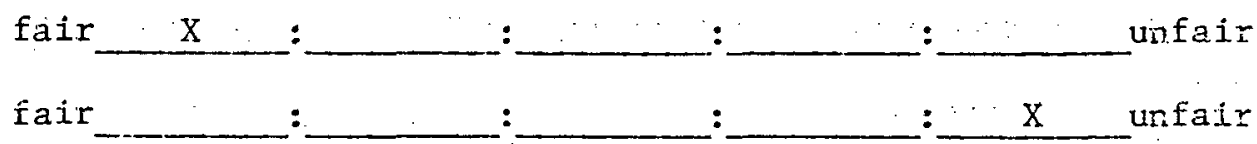

If you feel that the concept is quite closely related to one or the other end of the scale (but not extremely) you should place your check-marks as foliows:

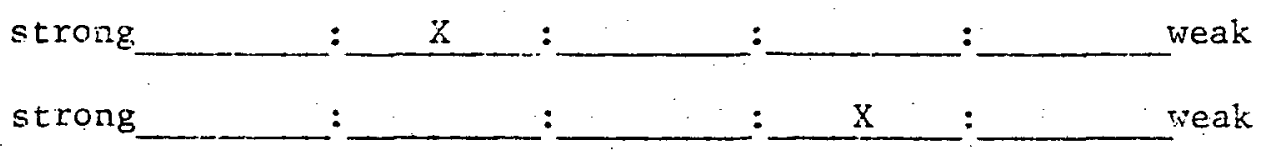

If you consider the concept to be about average, or if the scale just does not fit the concept at all, then you should place your check mark in the niddle space:

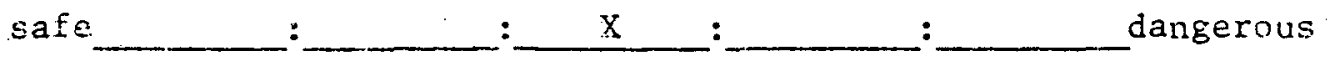
MPORTANT:

1. Place your check-marks in the middle of spaces, not on the boundaries: 
2. Be sure you check every scale for every concept--do not omit any.

3. Never put more than ONE check-mark on a single scale. Sometimes you may feel as though you've had the same item before on the test. Thjs vijl not be the case, so, do not look back and forth through the items. Do not try to remember how you checked similar items earlier in the test. Make each item a separate and independent judgment. Do not worry or puzzle over individual items. It is your first impressions, the immediate "thought" about the concept we want. On the other hand, please do not be careless, because we want your true impressions.

If you do not know a word, we will pronounce it for you. But, we cannot tell you what it means.

Thank you so much for your help and your honesty in answering each item exactly how you feel. 
GOD'S ATTJTUDE TOWARD SINEERS IS . .

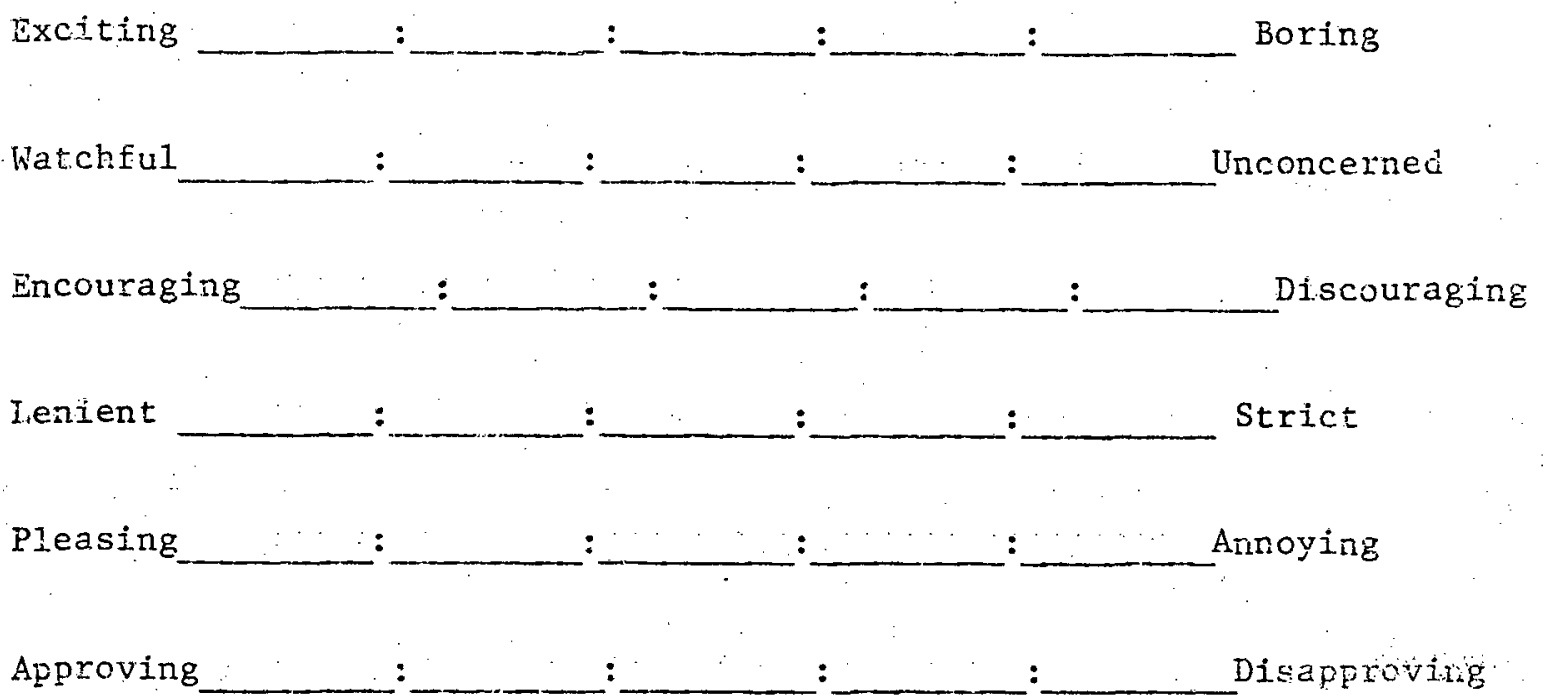

Hot

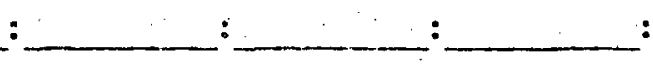

Cold

Easy

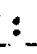

$\because$

:

Hard

Willing : : Unwilling

Understanding : Inảifferent 
Exciting $\therefore$ : : Boring

Watchful $: \quad:$ Unconcerned

Encouraging : $-$ Discouraging

Lenient. $\therefore$ : : : Strict

Pleasing : $:$ : : Anmoying Approving : $:$ $:$ Disapproving

HoL : : $\therefore$ Colá Easy : : Hard Willing $\because$ : $\because$ Lnwilling

Understanding : : Indifferent 
GOD'S REQUIRENENTS FOR REACHTMG HEAVEN ARE . .

Exciting ::

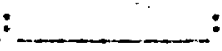
Boring

Watchful $: \quad:$ : Unconcerned

Encouraging : : Discouraging Lenient : : Strict

P1easing : $:$ : Annoying Approving : $:$ : : Disapproving

Hot: $:$ : $\operatorname{Cota}$ Easy : $:$ : : Hard Willing : $:$ : Unwilling Understanding : $:$ : Indifferent 
PRAYING TO GOD IS . .

Exciting :____ : Boring

Watchful : $\quad$ : : : Unconcerned

Encouraging : : : Discouraging

Lenient $\therefore$ : : Strict

Pleasing : : : Annoying

Approving : $-$ : : Disapproving Hot: : :$-$ Co1d Easy : : Hard Wi11ing $:$ : : Unwilling

understanding : $:$ : Indifferent 
Exciting : $:$ : Boring

Watchริน1 $\therefore \quad:$

Unconcerned

Encouraging : $\therefore$ : Discouraging Lenient : : : Strict

Pleasing : : : Annoying Approving : $\therefore$ Disapproving Hot $:$

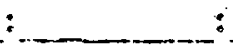
$\operatorname{cold}$ Easy $\therefore$ : : $:$ Hard Willing : : : Unwilling

Understanding $:$ : Indifferent 


\section{APPENDIX B}

FOFin II

ORIGINAL INSTKUEERT

Dear Student,

The purpose of this study is to meesure what you think about God. In taking this test, please make your choice on the basis of what you think and not on what someone wants you to think. No one vill know what you have written, so please be frank in your answers.

On each page of this booklet you will find a different concept to be juiged and beneath it a set of scales. You are to rate the concept on each of these scales in ordar. That is once you have finished a concept you are not to return to it, nor are you to work ahead before you finish a concept.

Here is how you are to do these scales: If you feel that the concept at the top of the page is very closely related to one end of rite scale, you should place your check-nark as follows:

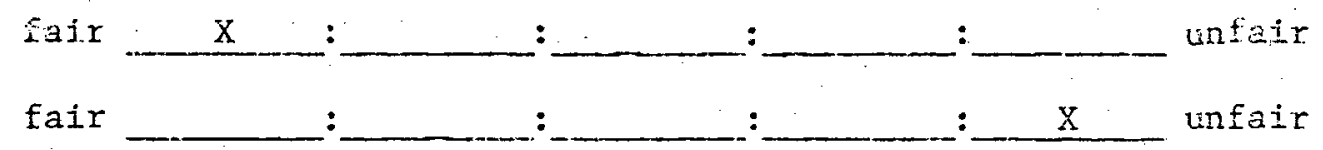

If you feel that the concept is quite closeiy related to one or the other end of the scale (but not extremely) you should place your check-marks as follows:

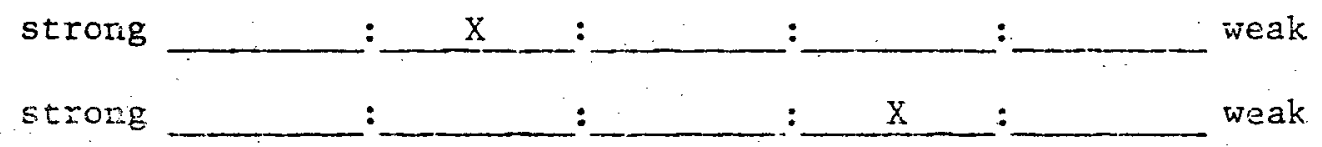

If you consider the concept to be about average, or if the scale just does not fit the concept at ali, ther you should place your check mark in the ridide space:

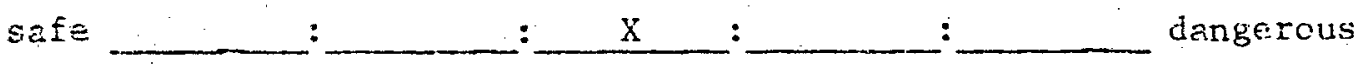
INPORTEIT:

1. Place your check-marks in the middle of spaces, not on the boundaries: 
2. Be sure you check every scale for every concept--do not omit any.

3. Never put rore than ONE check-nark on a single scale.

Sometimes you may feej. as though you've hat the same item before on the test. This will not be the case, so, do not look back and forth through the items. Do not try to rememter how you checked similar items earlier in the test. Make each item a separate and independent judgment. Do not worry or puzzle over individual items. It is your first impressions, the immeciate "thought" about the concept we -ant. On the other hand, please do not be careless, because we want your true impressions.

If you do not know a word, we will pronounce it for you. But, we cannot tell you what it means.

Thank you so much for your help and your honesty in answering each item exactly how you feel. 
GOD'S AITITUDE TOWARD SINNERS IS . .

Jcyf.u.

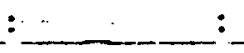

$:$

Sad

Modern

:

:

:

01d-fashioned

Essential : : $:$ $-$

Unnecessary

Useful $:$ : $:$ : Worthless

Alive : : Dead

Stable : : : : Changeabje.

Conorete : $\because$ : Abstrat

Sympathetic. : $:$ $\therefore$ Unsympatictic

Serious : : : : Humo rous

Particular $:$ : Lax 
Joyful : : : : Sad

Modern :

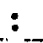
O1d-fashioned

Essential $: \quad:$ $: \quad:$

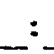
Unnecessary

Useful $\therefore \quad:$ $-$ Worthless

Alive : : $: \cdots$ Dead

Stabie : : : $\therefore$ Changeable

Concrete $\therefore$ $:$ : : Abstract

Sympathetic : $\therefore$ Unsympathetic

Serious $:$ : Humorous

Particular $\therefore$ : Lax 


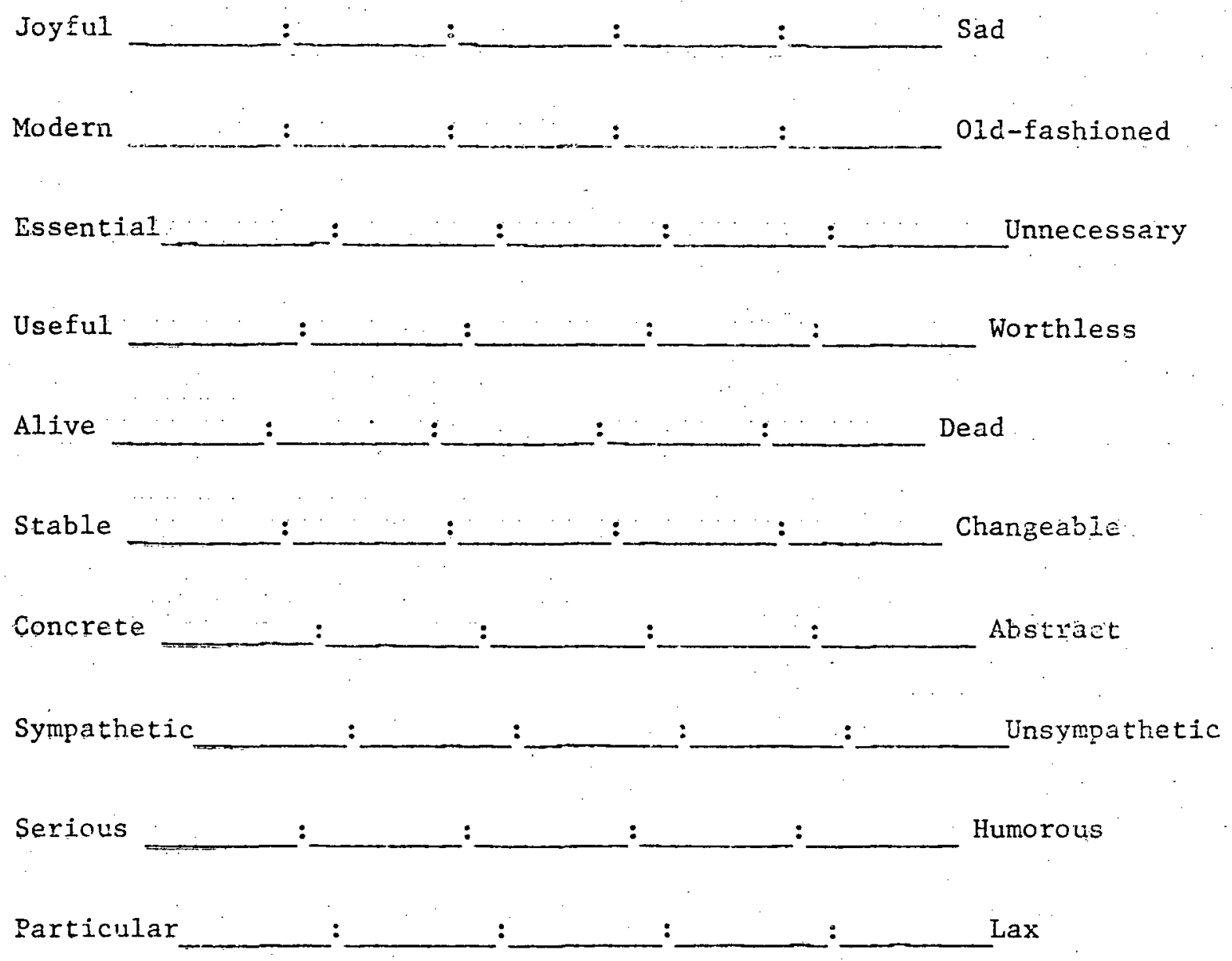


PRAYTNG TO GOD IS . .

Joyfu1 $\therefore$ : : : Sad

Modern : : : : 01d-fashinned

Essential : : : Unnecessary

Useful $-$ : : Worthless

Alive : : Dead

Stable $:$ $:$ : Changeabie Concrete $:$ $\therefore$ $:$ : Abstract Sympathetic $:$ : Unsympathetic

Serious : : $:$ Huniorous

Particular : : Lax 
TRUE CHRISTIANS ARE . .

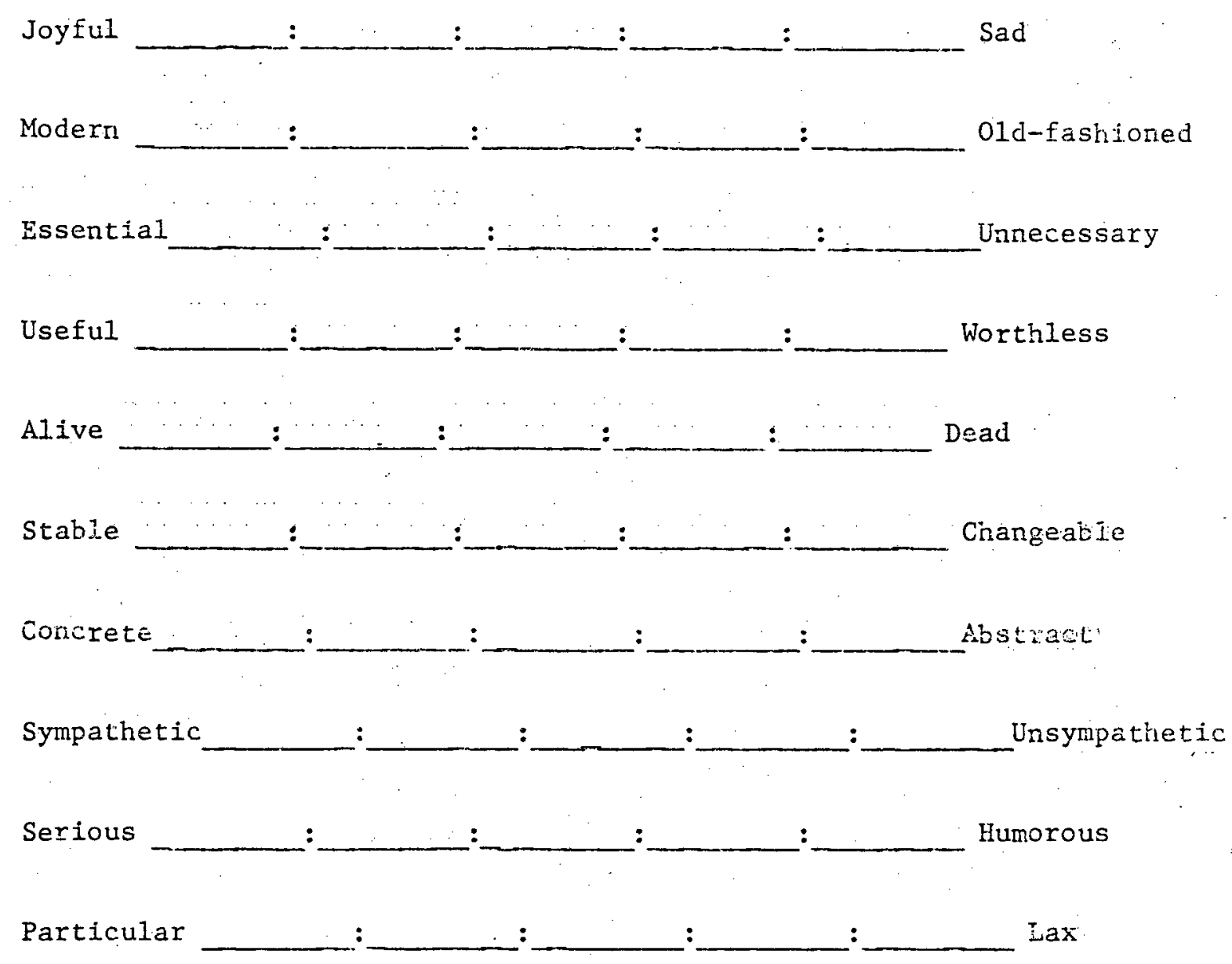


GESDE

APPENDIX C

Dear Student, TINAL INSTRUMEMI

The purpose of this atudy is to measure what you thind about God. In taking this test, please make your cholce on the basis of what you think and not on whet someone wants you to think. No one will kriow what you have written, so piease be frate in your answers.

Or each page of this booklet you vill find a different concept to be judged and beneath it a set of scales. Wou ate to race the concept on each of these scales in ordez. That ls; once you have finished a concept you are not to retuin to 1 , nor are you to werk ahead before you finish a concept.

Here is how you are to do these scales: If you feel that the concept at the top of the page is very closejy related to one end of the scrie, you should place your check-mark as follows:

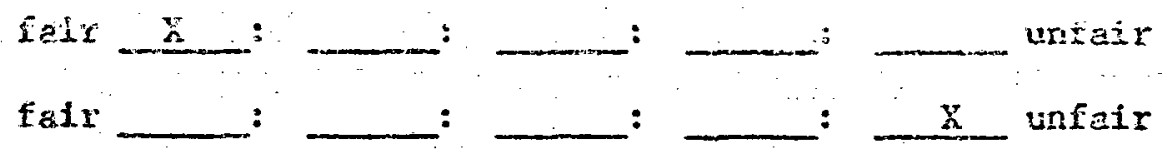

If you feel that the concept is guite ciosciy related to one or the other end of the scale (but not extremely) you should place your checirwarks as follows:

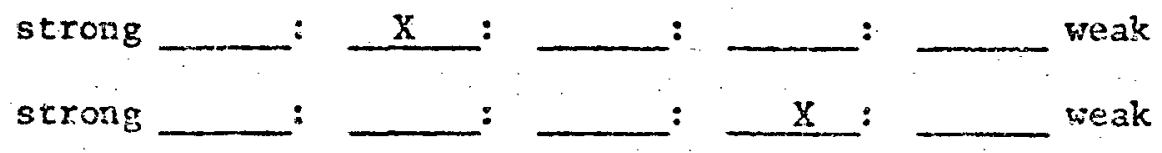

If you consider the concept to be about aversge, or if the scale just does not fit the concept at all, then you should place your checktark in the taldie space:

safe
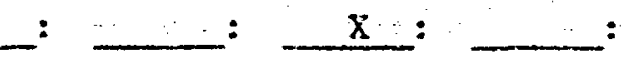
dangexous

INPORTANT:

1. Place your check-marks In the middle of spaces, not on the boundaries;

THIS

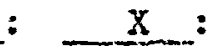
Nor TIIS $x$ 
2. Be sure you check every scale for every concept--do not omit any.

3. Never put more thari CNE check-nark on a single scale.

Sornetimes ycu may feel as though you've had the sane item before on the test. This will not be the case, so, do not look back and forth through the items. Do not try to remember how you checked slratlar items earlier in the test. Make each 1tern a separate and independent judgment. Do not worry or puzzle over individual items. It is your first impressions, the immediate "thought" about the concept ve want. On the other hand, please do not be careless, because we want your true impressions.

If you do not know a word, we will pronounce it for you. But, we cannot teII you what it means.

Thank you so mich for your help and your honesty in answering each 1tch exachly how. you feed. 
GOD'S AMTTUDE TOHARD SINNERS IS ....

Exciting

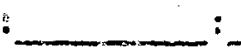
: : Boring

Encouraging $\therefore$ : $-$ : Discouraging

01.d-Fashioned : :: : Moderri

Usefu? $:$ $\therefore$ - Worthese

strset $\therefore$ $\div$

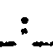
: Ienient

Dead : $-$ : : Alive

Pleastrg $-$ : : : Annoy'ng

Changeatie $\therefore$ : - Stable

Gonerete : : : Abstract

Sympathetis : $:$ : : Unsyngathetic

Disapproving : : : : : Approving

และป $\therefore$ $:$ : Easy

mderstanding : : : : Indiffererk 
GOD'S SABBATH IS ....

Exciting : : $:$ : Boring

Encouraging : : : Discouraging 01d-Fashioned : $:$ : : Modern

Usef:I : ; : : : Wortnless

Strict $-$ $:$ : : : Lenient

Dead : : : : Alive

Pleasing : : $\therefore$ : Annoyirg

Changeable

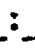
: : : Stable

Concrete $\therefore$ $\therefore$ : : Abstract

Sympathetic : : : : Unsympathetic

Dtsapproving : $:$ : Approving

Hard $:$ $-$ : Easy

Understanding : $:$ : : Indiffarent 
PEATHG TO GOD IS ....

Ex=1ting : : $\therefore$ : Boring

Encouraging : : : : Discouraging

old-Fashicned : $\therefore$ $\therefore$

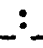
- Modern

Useful $:$ :$\therefore$ : Worthless

Strict $:$ : : : Lenient

Dead $:$ : : : Allve

Pleasing $\therefore$ : : : Annoying

Changeable $:$ $-$ : Stable

Concrete : : : : Abstract

Sympathetic $-$ $\therefore$ : : Unsympathetic Disapproving :: : : Approving

Hard : $:$ $:$ : Easy $:$ : : Indifferent 
Exeiting : :

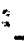
: Boring

Encouraging : : : : Discouraging

OId-Fashioned $\therefore$ : : $-$ : Modern

Useful $:$ $\therefore$ $:$ : Horthiess

Strict : $:$ : Lenient

Dead $\therefore$ : : Alive

pleasing : : $\therefore$ : Annoying

Changeable $-$ : : : Stable

Concrete : : $\therefore$ $\therefore$ Abstract

Sympathetic : : : : : Unsympathetic

Disapproving : : : : : Approving

Hard $\div$ : : : Easy

Understanding

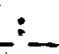
$:$ : : Indifferent 
Exciting : : : : Boring

Encouraging $\therefore$ : : Discouraging

old-Fashioned : $\therefore$ : : - Nodern

UsefuI : : : : Horthless

Strict $-$ $:$ : : Lenient

Dead : : : : Alive

Pleasing : : : Annoying

Changeable : $-$ : : Stable

Concrete

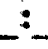
$\therefore$ : - Abstract

Sympathetic

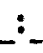
$\therefore$ : : Unsympathetic Disapproving : : : : Approvirg

Hard $:$ : : : Easy

Understanding $-$ $-$ : Indifferent 


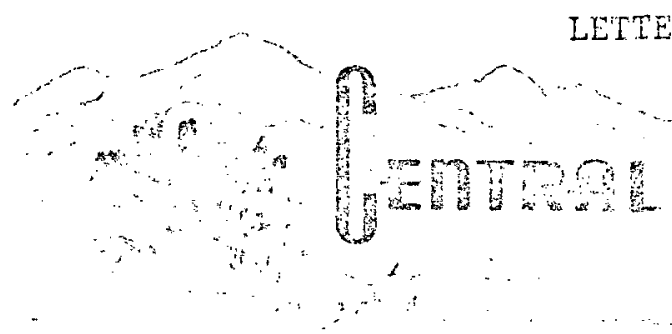

March 17, 1972 office of:

Department of Eucotion

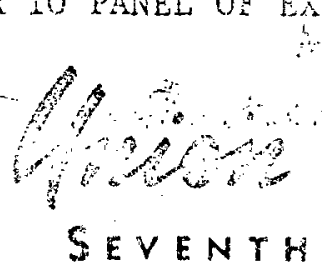

$S E V$ EPRTS

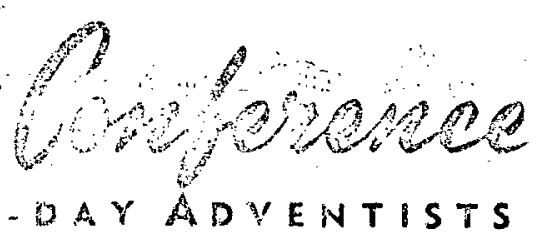

Phone $408-2313$

45.7 CALVERT STREET LIRCOLN, NEARASKA 68506

Nisiling Addresis P. O. Box 6127

Dr. Robert Wagner, Supt. of Education

Washington Conference of SDA

P. O. Box 1585

Seâtile, Washington 98103

Dear Dr. Wagner:

As you may know, for the last two consecutive years I have been attending Aridrews University during the winter and spring quarter. I now have one quarter of work Jeve and the requirements for an MA in Educational Foundations-Psychology will be completed.

The students at Andrews have a choice of doing two projects or a thesis. I chose to do the thesis and herein lies my reason for writing you.

The objective of my thesis is to develop a reliable and vaidi instrument that will measure a student's attitude toward God." The instrument is patterned after 0sgood's Sematic Differential i,e. concepts which can be judged by rating pairs of bipolar adjectives on a scale of five.

The final items were chosen only after two item analyses had been run to find the most discriminatcry adjective pairs. A factor analysis extracting two factors wis aiso rur to see if the concepts. were stable. A correlation of congruence was done and the concepts showed a high degree of stability.

Reliability will be determined by the test-retest method and the first administration for this has been done. In three weeks the second administration will take place.

Validity, of course, is difficult to determine except by a panel of experts. I am writing to you in the hope that you will serve as one of these experts. There are two parts to the evaluation I wish you to do. (1) Would you please pick thirteen out of the jist of twenty adjective pairs on Sheet A that you think will work best in jujging the five concepts listed at the top of that sheet? (2) The instrument and evaluation sheet are in the sealed envelope $B$. Would you please look over the instrument and evaluate it on the basis of the itenis included on the evaluation sheet? Please feel free to make any additional comments and/or suggestions. A self-addressed envelope to my Andrews sduress has been inciuded for your convenience.

I. would appreciate receiving your response at your earliest convenience. The first draft of the thesis must be in my riay 1. Thank you for your cooperation.

Sincerely,

Joyce A. Mozse, Elenentary Supervisor

JNM:im

Enclosures 


\section{Five Concepts:}

God's attitude towerd sinners is.....

God's Sabbath is.....

Praying to God Is.....

God's Requirements for Reaching Heaven are....

True Christians are.....

Adjectives: Please pick the best thirteen

1. Erciting - Boring

2. Lenient - Strict

3. Undergtanding - Indifferent

4. Easy - Hard

5. Encouraging - Discouraging

6. Serious - Humorous

7. Particular - Lax

8. 01d-fashloned - Modern

9. Approving - Dtsapproving

10. Sympathetic - Unsympachetic

11. Essential - Unnecessary

12. Jsefü - Worchiess

13. Concrete - Abetract

14. Changeable - Stable

15. Pleasting - Anroying

16. Alive - Dead

17. Joyful - Sad

13. Natchiful - Unconcerned

19. W1ling - Urwilling

20. Fermiseive - Dictatorial 
lecse rate the instrument on the foliowing basts:

1. Are the instructions clear and understandable by students in gzades $5-3$ ?

Poor : $\therefore$ : : Superior

2. Do the concepts reflect attitudes toward various aspects of the character of God and the student's relationship to $1 \mathrm{H}$ ?

Posr $\therefore$ $\therefore$ : : Superior

3. Do the adjective pairs reflect an evaluative meaning conceraing the five concepts listed?

Poor $:$ : : : Superior

4. Does the instrument impress you with the fact that 10 will yleld results that will validly measure what students think about God?

Poor : :: : Superior

5. Do you have additional coments or auggestions? 


\section{APPENDIX G}

D MAIRICES TEACHER A AND - ELEVEN STUDENTS

\begin{tabular}{ccccccc}
\hline Concept & 1 & \multicolumn{2}{c}{ TEACHER A } & & 4 & 5 \\
\hline 1 & 0 & 4 & 5.657 & 4 & 3.605 \\
2 & 4 & 0 & 4 & 0 & 2.236 \\
3 & 5.657 & 4 & 0 & 4 & 2.236 \\
4 & 4 & 0 & 4 & 0 & 2.236 \\
5 & 3.605 & 2.236 & 2.236 & 2.236 & 0 \\
\hline
\end{tabular}

\begin{tabular}{cccccc}
\hline Concept & 1 & \multicolumn{2}{c}{ STUDENT 202 } & \multicolumn{2}{c}{ 202 } \\
\hline 1 & 0 & 5.831 & 4 & 4.583 & 3.742 \\
2 & 5.831 & 0 & 3.464 & 4.359 & 3.742 \\
3 & 4 & 3.464 & 0 & 4.123 & 3.464 \\
4 & 4.583 & 4.359 & 4.123 & 0 & 3 \\
5 & 3.742 & 3.742 & 3.464 & 3 & 0 \\
\hline
\end{tabular}

\begin{tabular}{cccccc}
\hline Concept & 1 & \multicolumn{2}{c}{ STUDENT 204 } & & \\
2 & 1 & 0 & 4 & 3 & 5 \\
\hline 1 & 0 & 0 & 4 & 3 & 1 \\
2 & 0 & 4 & 0 & 1 & 1 \\
3 & 4 & 4 & 1 & 0 & 0 \\
4 & 3 & 3 & 1 & 0 & 0 \\
5 & 2 & 1 & & & 5 \\
\hline
\end{tabular}




\begin{tabular}{cccccc}
\hline Concept & 1 & \multicolumn{2}{c}{ STUDENT 211 } & & \\
\cline { 4 - 5 } 1 & 0 & 4.472 & 3.162 & 3.873 & 2.828 \\
2 & 4.472 & 0 & 4.583 & 4.123 & 5.657 \\
3 & 3.162 & 4.583 & 0 & 2.646 & 2.828 \\
4 & 3.873 & 4.123 & 2.646 & 0 & 3.601 \\
5 & 2.828 & 5.657 & 2.828 & 3.601 & 0 \\
\hline
\end{tabular}

\begin{tabular}{cccccc}
\hline & \multicolumn{4}{c}{ STUDENT 216 } & \\
Concept & 1 & $\frac{2}{3}$ & 4 & 5 \\
\hline 1 & 0 & 5 & 5.099 & 5.657 & 6.557 \\
2 & 5 & 0 & 3.601 & 3.601 & 4.123 \\
3 & 5.099 & 3.601 & 0 & 2 & 2.646 \\
4 & 5.657 & 3.601 & 2 & 0 & 2.646 \\
5 & 6.557 & 4.123 & 2.646 & 2.646 & 0 \\
\hline
\end{tabular}

\begin{tabular}{|c|c|c|c|c|c|}
\hline \multirow[b]{2}{*}{ Concept } & \multirow[b]{2}{*}{1} & \multicolumn{2}{|c|}{ STUDENT 218} & \multirow[b]{2}{*}{4} & \multirow[b]{2}{*}{5} \\
\hline & & 2 & 3 & & \\
\hline 1 & 0 & 8.246 & 8.307 & 8.544 & 7.681 \\
\hline 2 & 8.246 & 0 & 4.123 & 3.601 & $4: 123$ \\
\hline 3 & 8.307 & 4.123 & 0 & 2.282 & 3.162 \\
\hline 4 & 8.544 & 3.601 & 2.282 & 0 & 2.449 \\
\hline 5 & 7.681 & 4.123 & 3.162 & 2.449 & 0 \\
\hline
\end{tabular}




\begin{tabular}{cccccc}
\hline Concept & 1 & \multicolumn{4}{c}{ STIDENT 209 } \\
\hline 1 & 0 & 5.099 & 4.472 & 4.472 & 4.359 \\
2 & 5.099 & 0 & 3.162 & 2.449 & 3.873 \\
3 & 4.472 & 3.162 & 0 & 3.464 & 3.317 \\
4 & 4.472 & 2.449 & 3.464 & 0 & 2.646 \\
4 & 4.359 & 3.873 & 3.317 & 2.646 & 0 \\
\hline
\end{tabular}

\begin{tabular}{cccccc}
\hline & & \multicolumn{2}{c}{ STUDENT 223 } & & \\
\cline { 5 - 6 } Concept & 1 & 2 & 3 & 4 & 5 \\
\hline 1 & 0 & 5.292 & 4.359 & 3.464 & 7 \\
2 & 5.292 & 0 & 5.745 & 4.690 & 8.124 \\
3 & 4.359 & 5.745 & 0 & 2.236 & 5.196 \\
4 & 3.464 & 4.690 & 2.236 & 0 & 5.568 \\
5 & 7 & 8.124 & 5.196 & 5.568 & 0 \\
\hline
\end{tabular}

\begin{tabular}{cccccc}
\hline Concept & 1 & \multicolumn{2}{c}{ STUDENT 225} & & \\
2 & 3 & 5 & 2.646 & 4.123 \\
1 & 0 & 3.317 & 5 & 5 \\
2 & 3.317 & 0 & 3.162 & 2.449 & 2.828 \\
3 & 5 & 3.162 & 0 & 4 & 3.464 \\
4 & 2.646 & 2.449 & 4 & 0 & 4 \\
5 & 4.123 & 2.828 & 3.464 & 4 & 0 \\
\hline
\end{tabular}




\begin{tabular}{|c|c|c|c|c|c|}
\hline \multirow[b]{2}{*}{ Concept } & \multirow[b]{2}{*}{1} & \multicolumn{2}{|c|}{ STUDENT 226} & \multirow[b]{2}{*}{4} & \multirow[b]{2}{*}{5} \\
\hline & & 2 & 3 & & \\
\hline 1 & 0 & 0 & 2.828 & 4.899 & 4 \\
\hline 2 & 0 & 0 & 2.828 & 4.899 & 4 \\
\hline 3 & 2.828 & 2.828 & 0 & 2.828 & 2.828 \\
\hline 4 & 4.899 & 4.899 & 2.828 & 0 & 2.828 \\
\hline 5. & 4 & 4 & 2.828 & 2.828 & 0 \\
\hline
\end{tabular}

\begin{tabular}{|c|c|c|c|c|c|}
\hline \multirow[b]{2}{*}{ Concept } & \multirow[b]{2}{*}{1} & \multicolumn{2}{|c|}{ STUDENT 227} & \multirow[b]{2}{*}{4} & \multirow[b]{2}{*}{5} \\
\hline & & 2 & 3 & & \\
\hline 1 & 0 & 8.185 & 8 & 9.747 & 9.327 \\
\hline 2 & 8.185 & 0 & 8.660 & 8.367 & 6.782 \\
\hline 3 & 8 & 8.660 & 0 & 5.568 & 9.327 \\
\hline 4 & 9.747 & 8.367 & 5.568 & 0 & 8.602 \\
\hline 5 & 9.327 & 6.782 & 9.327 & 8.602 & 0 \\
\hline
\end{tabular}

\begin{tabular}{cccccc}
\hline & & \multicolumn{2}{c}{ STUDENT 232} & & \\
\cline { 5 - 5 } Concept & 1 & 2 & 3 & 4 & 5 \\
\hline 1 & 0 & 2.449 & 6.164 & 4.358 & 4 \\
2 & 2.449 & 0 & 5.657 & 2.646 & 3.464 \\
3 & 6.164 & 5.657 & 0 & 6.403 & 4 \\
4 & 4.353 & 2.646 & 6.403 & 0 & 4.796 \\
5 & 4 & 3.464 & 4 & 4.796 & 0 \\
\hline
\end{tabular}


APPENDIX H

D MATRICES TEACHER B AND TWELVE STUDDNTS

\begin{tabular}{|c|c|c|c|c|c|}
\hline \multirow[b]{2}{*}{ Concept } & \multirow[b]{2}{*}{1} & \multicolumn{2}{|c|}{ TEACHER B } & \multirow[b]{2}{*}{4} & \multirow[b]{2}{*}{5} \\
\hline & & 2 & 3 & & \\
\hline 1 & 0 & 5.196 & 5.292 & 4 & 5.659 \\
\hline 2 & 5.196 & 0 & 3.742 & 3 & 5.568 \\
\hline 3 & 5.292 & 3.742 & 0 & 4.899 & 5.477 \\
\hline 4 & 4 & 3 & 4.899 & 0 & 5.745 \\
\hline 5 & 5.659 & 5.568 & 5.477 & 5.745 & 0 \\
\hline
\end{tabular}

\begin{tabular}{|c|c|c|c|c|c|}
\hline \multirow[b]{2}{*}{ Concept } & \multirow[b]{2}{*}{1} & \multicolumn{2}{|c|}{ STUDENT 237} & \multirow[b]{2}{*}{4} & \multirow[b]{2}{*}{5} \\
\hline & & 2 & 3 & & \\
\hline 1. & 0 & 4.899 & 5.568 & 2 & 7.141 \\
\hline 2 & 4.899 & 0 & 3.601 & 4 & 5.745 \\
\hline 3 & 5.568 & 3.601 & 0 & 5.196 & 4.472 \\
\hline 4 & 2 & 4 & 5.196 & 0 & 7 \\
\hline 5 & 7.141 & 5.745 & 4.472 & 7 & 0 \\
\hline
\end{tabular}

\begin{tabular}{cccccc}
\hline Concept & 1 & \multicolumn{2}{c}{ STUDENT 240} & & \\
2 & 3 & 4 & 5 \\
\hline 1 & 0 & 2.646 & 5.099 & 5 & 5.568 \\
2 & 2.646 & 0 & 4.123 & 4.123 & 5.099 \\
3 & 5.099 & 4.123 & 0 & 4 & 3.873 \\
4 & 5 & 4.123 & 4 & 0 & 5.385 \\
5 & 5.558 & 5.099 & 3.873 & 5.385 & 0 \\
\hline
\end{tabular}




\begin{tabular}{|c|c|c|c|c|c|}
\hline \multirow{2}{*}{ Concept } & \multirow{2}{*}{$\begin{array}{c}1 \\
\vdots=1\end{array}$} & \multicolumn{2}{|c|}{ STUDENT 243} & \multirow[b]{2}{*}{4} & \multirow[b]{2}{*}{5} \\
\hline & & $\cdot 2$ & 3 & & \\
\hline 1 & $\therefore \quad 0$ & 6.782 & 5.568 & 8.124 & 4.796 \\
\hline 2 & .6 .782 & 0 & 6.083 & 6.164 & 3 \\
\hline 3 & 5.568 & 6.083 & 0 & 5 & 4.690 \\
\hline 4 & $=8.124$ & 6.164 & 5 & 0 & 6.557 \\
\hline \multirow[t]{2}{*}{5} & $\therefore 4.796$ & 3 & 4.690 & 6.557 & 0 \\
\hline & 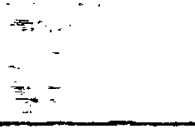 & & & & \\
\hline \multirow[b]{2}{*}{ Concept } & \multicolumn{3}{|c|}{ STUDENT 246} & \multirow[b]{2}{*}{4} & \multirow[b]{2}{*}{5} \\
\hline & 1 & 2 & 3 & & \\
\hline 1 & 0 & 3.606 & 2.646 & 2.236 & 2.449 \\
\hline 2 & 3.606 & 0 & 4.690 & 4 & 4.123 \\
\hline 3. & 2.646 & 4.690 & $i$ & 1.414 & 2.236 \\
\hline 4 & 2.236 & 4 & 1.414. & 0 & 1 \\
\hline 5 & 2.449 & 4.123 & 2.236 & 1 & 0 \\
\hline
\end{tabular}

\begin{tabular}{|c|c|c|c|c|c|}
\hline \multirow[b]{2}{*}{ Concept } & \multirow[b]{2}{*}{1} & \multicolumn{2}{|c|}{ STUDENT 247} & \multirow[b]{2}{*}{4} & \multirow[b]{2}{*}{5} \\
\hline & & 2 & $\overline{3}$ & & \\
\hline 1 & 0 & 5.477 & 5 & 5.099 & 4.796 \\
\hline 2 & 5.477 & 0 & 5.385 & 3.742 & 3.606 \\
\hline 3 & 5 & 5.385 & 0 & 3.742 & 3.606 \\
\hline 4 & 5.099 & 3.742 & 3.742 & 0 & 1.732 \\
\hline 5 & 4.796 & 3.606 & 3.606 & 1.732 & 0 \\
\hline
\end{tabular}




\begin{tabular}{|c|c|c|c|c|c|}
\hline \multirow[b]{2}{*}{ Concept } & \multirow[b]{2}{*}{ i } & \multicolumn{2}{|c|}{ STUDENT 250} & \multirow[b]{2}{*}{4} & \multirow[b]{2}{*}{5} \\
\hline & & 2 & 3 & & \\
\hline 1. & 0 & 8.062 & 8.367 & 9.165 & 10.1 .98 \\
\hline 2 & 8.062 & 0 & 5.170 & 7.483 & 7.280 \\
\hline 3 & 8.367 & 5.170 & 0 & 6.325 & 5.477 \\
\hline 4 & 9.165 & 7.483 & 6.325 & 0 & 4.472 \\
\hline 5 & 10.198 & 7.280 & 5.477 & 4.472 & 0 \\
\hline
\end{tabular}

\begin{tabular}{ccccccc}
\hline Concept & 1 & \multicolumn{2}{c}{ STUDENT 252} & & 5 \\
\hline 1 & C & 3.742 & 4.583 & 1.414 & 6.633 \\
2 & 3.742 & 0 & 4.583 & 3.464 & 5.292 \\
3 & 4.583 & 4.583 & 0 & 4.472 & 3.601 \\
4 & 1.414 & 3.464 & 4.472 & 0 & 6.164 \\
5 & 6.633 & 5.292 & 3.601 & 6.164 & 0 \\
\hline
\end{tabular}

\begin{tabular}{cccccc}
\hline Concept & 1 & \multicolumn{2}{c}{ STUDENT 253 } & & \\
\cline { 5 - 6 } 1 & 0 & 3.317 & 4 & 5.099 & 4.690 \\
2 & 3.317 & 0 & 2.236 & 3.317 & 2.646 \\
3 & 4 & 2.236 & 0 & 2.449 & 1.414 \\
4 & 5.099 & 3.317 & 2.449 & 0 & 1.414 \\
5 & 4.690 & 2.645 & 1.414 & 1.414 & 0 \\
\hline
\end{tabular}




\begin{tabular}{|c|c|c|c|c|c|}
\hline \multirow[b]{2}{*}{ Concept } & \multirow[b]{2}{*}{1} & \multicolumn{2}{|c|}{ STUDENT 257} & \multirow[b]{2}{*}{4} & \multirow[b]{2}{*}{5} \\
\hline & & 2 & 3 & & \\
\hline 1 & 0 & 7.071 & 6.856 & 5.292 & 7.071 \\
\hline 2 & 7.071 & 0 & 1 & 3.742 & 0 \\
\hline 3 & 6.856 & 1 & 0 & 3.606 & 1 \\
\hline 4 & 5.232 & 3.742 & 3.605 & 0 & 3.742 \\
\hline 5 & 7.071 & 0 . & 1 & 3.742 & 0 \\
\hline
\end{tabular}

\begin{tabular}{cccccc}
\hline Concept & 1 & \multicolumn{2}{c}{ STUDENT 259} & & \\
\hline & 1 & 3 & 4 & 5 \\
\hline 1 & 0 & 7.483 & 6.245 & 6 & 7.071 \\
3 & 7.483 & 0 & 2.646 & 6.481 & 5.292 \\
4 & 6.245 & 2.646 & 0 & 4.583 & 5 \\
5 & 6 & 6.481 & 4.583 & 0 & 5.831 \\
\hline
\end{tabular}

\begin{tabular}{cccccc}
\hline Concept & \multicolumn{5}{c}{ STUDENT 260 } \\
\cline { 3 - 5 } 1 & 0 & 4.123 & 4 & 2.646 & 4.796 \\
\hline 2 & 4.123 & 0 & 1.732 & 4 & 4.898 \\
3 & 4 & 1.732 & 0 & 3.872 & 5 \\
4 & 2.646 & 4 & 3.872 & 0 & 3.741 \\
5 & 4.796 & 4.898 & 5 & 3.741 & 0 \\
\hline
\end{tabular}




\begin{tabular}{cccccc}
\hline & & \multicolumn{2}{c}{ STUDENT 262} & & \\
\cline { 5 - 6 } Concept & 1 & 2 & 3 & 4 & 5 \\
\hline 1 & 0 & 4.123 & 4 & 4.690 & 4 \\
2 & 4.123 & 0 & 1.732 & 4 & 4.898 \\
3 & 4 & 1.732 & 0 & 3.872 & 5 \\
4 & 4.690 & 4 & 3.872 & 0 & 3.741 \\
5 & 4 & 4.898 & 5 & 3.741 & 0 \\
\hline
\end{tabular}

